\title{
Regulating Systemic Risk in Insurance
}

\author{
Daniel Schwarcz† \& Steven L. Schwarcz††
}

\begin{abstract}
As exemplified by the dramatic failure of AIG, insurance companies and their affiliates played a central role in the 2008 global financial crisis. It is therefore not surprising that the Dodd-Frank Act-the United States' primary legislative response to the crisis-contained an entire title dedicated to insurance regulation, which has traditionally been the responsibility of individual states. The most important insurance-focused reforms in Dodd-Frank empower the Federal Reserve Bank to impose an additional layer of regulatory scrutiny on top of state insurance regulation for a small number of "systemically important" nonbank financial companies, such as AIG. This Article argues, however, that in focusing on the risk that an individual insurance-focused, nonbank financial company could become systemically significant, Dodd-Frank largely overlooked a second, and equally important, potential source of systemic risk in insurance: the prospect that correlations among individual insurance companies could contribute to or cause widespread financial instability. In fact, this Article argues that there are often substantial correlations among individual insurance companies with respect to both their interconnections with the larger financial system and their vulnerabilities to failure. As a result, the insurance industry as a whole can pose systemic risks that regulation should attempt to identify and manage. Traditional statebased insurance regulation, this Article contends, is poorly adapted to accomplishing this given the mismatch between state boundaries and systemic risks, as well as states' limited oversight of noninsurance financial markets. As such, this Article suggests enhancing the power of the Federal Insurance Office-a federal entity primarily charged with monitoring the insurance industry-to supplement or preempt state law when states have failed to satisfactorily address gaps or deficiencies in insurance regulation that could contribute to systemic risk.
\end{abstract}

$\dagger$ Associate Professor and Solly Robins Distinguished Research Fellow, University of Minnesota Law School.

†† Stanley A. Star Professor of Law \& Business, Duke University School of Law.

We thank, for helpful comments, Claire A. Hill, Richard Hsia, Patricia A. McCoy, Brett McDonnell, Craig Merrill, Gregory R. Niehaus, Gabe Shawn Varges, Robert Weber, Steven N. Weisbart, participants in faculty workshops at the London School of Economics, Duke University School of Law, University of California Berkeley School of Law, University of Michigan School of Law, University of Virginia School of Law, and University of Alabama School of Law, and the participants in the CCLS Roundtable on Systemic Risk and the Future of Insurance Regulation at Queen Mary University of London (sponsored by the university's Centre for Commercial Law Studies). We also thank Seth Bloomfield, Bryan Coe, Jonathan E. Cote, Joan C. Kerecz, Ori Sharon, Paulina Stanfel, and Edward Tang for valuable research assistance. Finally, we gratefully acknowledge financial support through a grant from the International Insolvency Institute Foundation and matching funds from the Duke Global Financial Markets Center. 


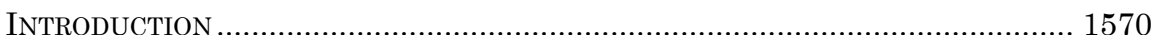

I. AN OvERVIEW OF US INSURANCE REgULATION AND SySTEMIC Risk.......... 1578

A. Pre-crisis US Insurance Regulation: State-Based Consumer Protection Regulation ............................................................. 1579

B. The Global Financial Crisis and Insurance ................................. 1584

C. The Post-crisis Regulatory Landscape: Federal Regulation of "Systemically Important" Nonbank Financial Companies . 1589

II. Systemic Risk In InsURANCE RESUlting FROM CORRELATIONS AMONG FIRMS......

A. Interconnections between Insurers and the Larger Financial System 1594

1. The central connection between insurers and the rest of the financial system: insurers as owners of financial assets. 1595

2. Other potential linkages between insurers and the financial system. 1605

B. Vulnerabilities of the Insurance System to Tail End Events ......... 1610

1. Catastrophe risk. 1611

2. Reinsurance opacity and interconnectedness....................... 1613

3. Insurers' guarantees against financial risk........................... 1618

4. Policyholder runs and guarantee-fund structure................... 1619

5. Systematic errors in life insurers' reserves. 1623

III. REGULATORY IMPLICATIONS: EMPOWERING THE FIO TO REGULATE Systemic Risk In INSURANCE RESULTING FROM CORRELATIONS AMONG FIRMS.

A. State Insurance Regulation and Systemic Risk ......................... 1627

B. One Option for Enhancing Federal Involvement in State Insurance Regulation: Expanding the FIO's Authority ....

CONCLUSION 1639

\section{INTRODUCTION}

Insurance companies played a central role in the 2008 global financial crisis. Nowhere is this clearer than in the case of American International Group (AIG), an insurance-focused financial enterprise whose receipt of $\$ 180$ billion from the federal government amounts to the largest bailout of a private company in history. ${ }^{1}$ Given AIG's prominence in the 2008 financial crisis,

1 William K. Sjostrom Jr, The AIG Bailout, 66 Wash \& Lee L Rev 943, 974-75 (2009); Mark Felsenthal and Lilla Zuill, US Government Increases AIG Bailout to \$150 $B l n$, Reuters (Nov 11, 2008), online at http://in.reuters.com/article/2008/11/10/idINIndia -36425020081110 (visited Nov 3, 2014). AIG Financial Products, a subsidiary of AIG that was most often identified as the cause of AIG's failure, was not itself an insurance company. See text accompanying notes 69-81. See also Jeffrey E. Thomas, Insurance Perspectives on Federal Financial Regulatory Reform: Addressing Misunderstandings and Providing a View from a Different Paradigm, 55 Vill L Rev 773, 773-77 (2010) (arguing 
it is hardly surprising that the Dodd-Frank Wall Street Reform and Consumer Protection Act ${ }^{2}$ - the United States' primary legislative response to the crisis-directly addresses the risk that a nonbank financial company like AIG could become "too big to fail." 3 In particular, the Act supplements insurance regulation by subjecting nonbank financial companies deemed systemically significant to enhanced regulation by the Federal Reserve Bank ("Fed"). 4 To date, three insurance-focused nonbank financial companies-including, of course, AIG-have been designated as systemically risky. ${ }^{5}$

AIG, however, was not the only insurance-focused financial company that played a role in the financial crisis. An entire segment of the insurance industry - the financial-guarantee insurers-dramatically destabilized financial markets as it became clear that these insurers would be unable to pay claims on policies insuring against the default of mortgage-backed securities. ${ }^{6}$ Meanwhile, various large, non-AIG, life insurance companies experienced substantial decreases in capital during the crisis

that "insurance had little, if any, role in the crisis" because "AIG's collapse was not an insurance problem"). However, AIG Financial Products was able to amass the risk that it did only by leveraging the financial strength of the AIG holding company, and by doing so, it directly imperiled AIG's many insurance companies. See Sjostrom, 66 Wash \& Lee L Rev at 958 \& $\mathrm{n} 88$ (noting that AIG was leveraging its credit rating, which allowed Financial Products to take on substantial risk). Moreover, a central cause of AIG's failure was a securities-lending program that lent out AIG insurers' safe securities and replaced them with mortgage-backed securities. See id at 961 ("Unfortunately, AIG Investments had invested a significant portion of the cash [that it received as collateral for lent securities] in residential mortgage-backed securities which had plummeted in value and liquidity.").

2 Pub L No 111-203, 124 Stat 1376 (2010).

3 See Simon Johnson and James Kwak, 13 Bankers: The Wall Street Takeover and the Next Financial Meltdown 200-13 (Pantheon 2010) (discussing the too-big-to-fail problem, and concluding that the regulatory solution is to prevent financial institutions from attaining this status and break up institutions that already have).

4 See Dodd-Frank $§ 113,124$ Stat at 1398-1402, codified at 12 USC $§ 5323$ (granting the Fed authority to supervise and regulate nonbank financial companies that, due to enumerated characteristics, pose a threat to the financial stability of the United States).

5 Fitch Ratings, Press Release, Non-bank SIFI Status Neutral to Insurance Ratings (June 4, 2013), online at https://www.fitchratings.com/gws/en/fitchwire/fitchwirearticle/Non -Bank-SIFI-Status?pr_id=792828 (visited Nov 3, 2014). A third insurer is currently appealing its designation as systemically risky. See Zachary Tracer and Ian Katz, MetLife Challenges Risk Tag, Sets Stage for Court Clash (Bloomberg Oct 3, 2014), online at http://www.bloomberg.com/news/2014-10-03/metlife-challenges-risk-tag-sets-stage-for-court -clash.html (visited Nov 3, 2014).

6 See Robert P. Bartlett III, Inefficiencies in the Information Thicket: A Case Study of Derivative Disclosures during the Financial Crisis, 36 J Corp L 1, 1-42 (2010) (examining the financial-guarantee industry's heavy exposure to complex credit derivatives leading up to the financial crisis). See also Part I.B. 
due to losses in their investment portfolios coupled with longterm guarantees to policyholders. ${ }^{7}$ Two of these companies received federal bailout funds through the Troubled Asset Relief Program (TARP), several more applied for bailouts, and many more were the beneficiaries of capital relief through ad hoc changes in accounting rules by the National Association of Insurance Commissioners (NAIC). ${ }^{8}$

Unlike AIG, none of the individual financial-guarantee insurers and virtually none of the life insurers that were implicated in the financial crisis were "too big to fail." Instead, these insurers were caught up in the crisis because of commonalities in their risk exposures and interconnections to the larger financial system. In the case of the financial-guarantee insurers, these commonalities involved an industry-wide trend toward insuring payment on complex-and risky-mortgage-backed securities. ${ }^{10}$ And in the case of life insurers, these commonalities involved guarantees on annuity products and investments in mortgagebacked securities. ${ }^{11}$ In each case, the result was that a number of insurance companies that were not individually too big to fail were collectively able to pose a material risk to the larger financial system. ${ }^{12}$

In contrast to its enhanced regulation of too-big-to-fail, insurance-focused financial firms such as AIG, Dodd-Frank did relatively little to address the prospect that clusters of insurance companies or entire segments of the insurance industry could collectively pose systemic risks because of commonalities in their

\footnotetext{
7 See US Government Accountability Office, Insurance Markets: Impacts of and Regulatory Response to the 2007-2009 Financial Crisis *9, 28-32 (GAO-13-583, June 2013) (“GAO Report”), online at http://www.gao.gov/assets/660/655612.pdf (visited Nov 3, 2014).

8 See Scott E. Harrington, The Financial Crisis, Systemic Risk, and the Future of Insurance Regulation, 76 J Risk \& Ins 785, 788 (2009) (identifying the insurance companies that applied for and received TARP funds, and noting the availability of ad hoc modifications).

9 See Marc Labonte, Systemically Important or "Too Big to Fail" Financial Institutions *1 (July 30, 2013), online at https://www.fas.org/sgp/crs/misc/R42150.pdf (visited Nov 3, 2014) (noting that only two nonbanks have been designated systemically important, or too big to fail, by the Financial Stability Oversight Council).

10 See Bartlett, $36 \mathrm{~J}$ Corp L at 4 (cited in note 6).

11 See GAO Report at *28-30 (cited in note 7).

12 For a discussion of the possibility that correlations among individual firms could result in systemic risk, see Ian Ayres and Joshua Mitts, Anti-herding Regulation, 4 Harv Bus L Rev *32-34 (forthcoming 2014), online at http://islandia.law.yale.edu/ayres/Anti -Herding\%20Regulation.pdf (visited Nov 3, 2014) (defining "systemic risk as the conditional correlation of asset returns of the financial system in response to events occurring to individual firms within it").
} 
risk exposures or interconnections with the larger financial system. ${ }^{13}$ Instead, Dodd-Frank left largely unchanged the traditional system of state-based insurance regulation for all but the small number of insurance-focused financial firms that are individually deemed systemically significant or that own a depository institution. ${ }^{14}$ As a result, the vast majority of insurers (other than health insurers) continue to be regulated solely by individual states rather than the federal government. ${ }^{15}$

This Article argues that Dodd-Frank's failure to address the prospect that systemic risk in insurance could arise outside of individual, too-big-to-fail institutions represents a substantial flaw in US financial regulation. It suggests that correlations among insurance companies-involving their products, investment strategies, or risk-management techniques, among other things - can themselves contribute to systemic instability. These correlations can arise from numerous sources including competition, insurance regulatory restrictions that apply equally to all insurers, ${ }^{16}$ shared suppositions and strategies embedded within the insurance industry, ${ }^{17}$ and rational herding among insurance companies and executives. ${ }^{18}$ Whatever their source, we argue that these correlations can contribute to systemic risk by producing substantial interconnections between entire segments of the insurance industry and the rest of the financial system, or by causing a risk of mass instability within the insurance industry itself.

In advancing the claim that the business of insurance can indeed be systemically risky, we part ways with much of the extant academic literature on the topic. ${ }^{19}$ Broadly speaking, this

\footnotetext{
13 See Part I.C.

14 See Scott E. Harrington, Insurance Regulation and the Dodd-Frank Act *11-12 (Networks Financial Institute Policy Brief, Mar 2011), online at http://ssrn.com/abstract $=1783904$ (visited Nov 3, 2014).

15 See David Zaring, It Is Time to Rethink Insurance Regulation, NY Times DealBook (NY Times Jan 22, 2014), online at http://dealbook.nytimes.com/2014/01/22/it -is-time-to-rethink-insurance-regulation (visited Nov 3, 2014).

16 See Charles K. Whitehead, Destructive Coordination, 96 Cornell L Rev 323, 34657 (2011) (discussing how regulation that promotes coordination can have perverse effects that increase risk).

17 See Geoffrey P. Miller and Gerald Rosenfeld, Intellectual Hazard: How Conceptual Biases in Complex Organizations Contributed to the Crisis of 2008, 33 Harv J L \& Pub Pol 807, 811-15 (2010).

18 See Erik F. Gerding, Law, Bubbles, and Financial Regulation 40 (Routledge 2014).

19 For analyses that largely dismiss the possibility that the insurance industry is systemically risky outside of certain limited, nontraditional activities, see, for example,
} 
literature has been spearheaded by economists who argue that the only real systemic risks associated with insurance involve "nontraditional" insurance activities or noninsurance activities engaged in by insurers. Within these abstract categories are usually included only the specific insurer (or insurer affiliate) activities that were most clearly implicated in the 2008 crisis, particularly writing derivatives and financial-guarantee insurance. These analyses often dismiss alternative potential sources of systemic risk in insurance because of the perceived lack of historical precedents. They also emphasize that the magnitudes of insurers' potential interconnections with one another or the larger financial system are not large enough to be systemically significant and that insurers' liabilities have historically been long-term, limiting the risk of a run on an insurer. For these reasons, they tend to conclude or suggest that even the limited insurance-oriented reforms embedded within Dodd-Frank are excessive. ${ }^{20}$

By contrast, we reject this historically bound methodology for assessing systemic risk in insurance. This approach, if employed in 2004, would have concluded that AIG's portfolio of credit default swaps (CDSs) could not be systemically risky due to its relatively small size at the time. It would have ignored as empirically unsupported the risk that the structure of AIG's

Richard Herring and Til Schuermann, Capital Regulation for Position Risk in Banks, Securities Firms, and Insurance Companies, in Hal S. Scott, ed, Capital Adequacy beyond Basel: Banking, Securities, and Insurance 15, 23-24 (Oxford 2005); Robert W. Klein, The Insurance Industry and Its Regulation: An Overview, in Martin F. Grace and Robert W. Klein, eds, The Future of Insurance Regulation in the United States 13, 28 (Brookings 2009) (observing that, with certain exceptions, "it is not clear that the insurance industry poses the kind of systemic risk to other markets as that posed by banks or other financial institutions"); Harrington, $76 \mathrm{~J}$ Risk \& Ins at 804 (cited in note 8); Mary A. Weiss, Systemic Risk and the U.S. Insurance Sector *2 (unpublished draft, Center for Insurance Policy \& Research, Feb 23, 2010), online at http://www.naic.org/documents/ cipr_weiss_systemic_risk_100223.pdf (visited Nov 3, 2014) ("[A]nalysis suggests that insurers are not instigators or the cause of systemic risk."); J. David Cummins and Mary A. Weiss, Systemic Risk and the U.S. Insurance Sector *30-39 (Department of Risk, Insurance, and Healthcare Management Working Paper, July 27, 2011), online at http://papers.ssrn.com/sol3/papers.cfm?abstract_id=1725512 (visited Nov 3, 2014) (finding that core activities of insurers pose little systemic risk, while noncore activities are more problematic). In another article, one of us has also briefly endorsed this view. See Daniel Schwarcz, Regulating Insurance Sales or Selling Insurance Regulation? Against Regulatory Competition in Insurance, 94 Minn L Rev 1707, 1753-54 (2010) (arguing that insurance "generally does not create substantial systemic risks ... [because] the availability and proper functioning of insurance is not a prerequisite to most systemically important economic activities").

20 See Parts I.A, I.C. 
CDS business-which allowed the company to write insurancelike products and book the premiums as pure profit while relying on complex and opaque internal risk models concluding that these guarantees would never be triggered-could produce systemic consequences.

Unlike this literature, we approach the regulation of systemic risk in insurance with a deep appreciation for the possibility that systemic risk can crop up in new and distinctive guises due to the massive complexity and interconnections that have evolved, and continue to evolve, within our financial system. ${ }^{21}$ For these reasons, the need for regulation of systemic risk in insurance must be determined in part by attempting to proactively anticipate new potential sources of systemic risk based on structural vulnerabilities of the insurance industry and structural interconnections between the insurance industry and the rest of the financial system. Although that analysis must be deeply informed by available empirical evidence, it should not assumeunlike most of the extant economics literature-that the future will resemble the past or present.

To illustrate these points, we review emerging evidence suggesting that insurers were partially responsible both for inflating the value of mortgage-backed securities prior to the crisis and for disrupting markets in these securities in the midst of the crisis. ${ }^{22}$ These effects were not the result of a single insurer's

21 See Insurance Oversight and Legislative Proposals, Hearing before the Subcommittee on Insurance, Housing and Community Opportunity of the Committee on Financial Services, 112th Cong, 1st Sess 54 (2011) (statement of Daniel Schwarcz, University of Minnesota Law School):

[T] he proposed legislation seems to ignore one of the central lessons of the 2008 Global Financial Crisis: that we do not always know what we do not know when it comes to systemic risk. ... [ I] t ensconces the traditional view that insurance activities pose limited systemic risk and restricts the capacity of federal regulators to learn as they go and adapt to evolving research and knowledge. It does this by effectively exempting insurers from the heightened prudential standards that ought to apply to systemically risky firms, by limiting the tools available to federal agencies to investigate systemic risk within insurance companies, and by undermining the capacity of federal regulators to respond to facts on the ground that reveal the threat of systemic risk.

22 See Craig B. Merrill, et al, Did Capital Requirements and Fair Value Accounting Spark Fire Sales in Distressed Mortgage-Backed Securities? *30-31 (NBER Working Paper No 18270, Aug 2012), online at http://www.nber.org/papers/w18270 (visited Nov 3, 2014) (concluding that, based on statistical evidence, insurance companies facing capitalization problems are more likely to sell mortgage-backed securities at lower prices); Craig B. Merrill, Taylor D. Nadauld, and Philip E. Strahan, Final Demand for Structured Finance Securities *2 (working paper, Mar 2014), online at http://ssrn.com/abstract $=2380859$ (visited Nov 3, 2014) (arguing that insurance companies distorted demand for 
investment strategy but were instead a product of numerous life insurers pursuing similar investment strategies in order to exploit regulatory restrictions and respond to common losses resulting from their issuances of annuity products containing embedded interest-rate guarantees. ${ }^{23}$ Although the magnitudes of these effects are unclear and contested, we focus our analysis on the structural connections that they reveal between the insurance industry and the rest of the financial system. In particular, these effects demonstrate that insurers' massive role as investors and as a source of funding in the US real estate and corporate sectors creates the risk that instability in insurance markets could trigger much broader financial consequences.

These and similar potential systemic risks suggest a need for a regulatory structure that is designed to proactively identify, assess, and manage new potential sources of systemic risk in insurance that are not localized within an individual company. Traditional state-based insurance regulation, this Article argues, is ill suited to meet these objectives. ${ }^{24}$ Individual states are likely to experience only a small amount of the harm that systemic events can produce in the economy writ large. ${ }^{25}$ States consequently have inadequate incentives to police against this risk, especially to the extent that doing so is in tension with their more traditional goals, be it consumer protection or premium tax collection. ${ }^{26}$ Even properly motivated state regulators and legislatures lack the perspective and expertise to manage systemic risk. States long ago lost most of their regulatory authority and expertise over the banking and securities industries, ${ }^{27}$ meaning that they do not have a global or even national perspective on the financial system as a whole. In fact, the fragmented nature of state regulation often prevents state regulators from developing a larger perspective on risks in the insurance industry itself. ${ }^{28}$

Although we conclude that Dodd-Frank's reforms of insurance regulation are insufficient to address systemic risk in insurance,

\footnotetext{
various asset-backed securities before the financial crisis). See also text accompanying notes $157-59$.

23 See text accompanying notes $156-63$.

24 See Part III.A.

25 See text accompanying notes 311-29.

26 See Richard B. Stewart, Madison's Nightmare, 57 U Chi L Rev 335, 351-52

(1990) (arguing that national markets require national regulation).

27 See text accompanying notes 331-34.

28 See text accompanying notes 338-44.
} 
we also argue that Dodd-Frank explicitly opened the door for one potentially effective solution to this shortcoming. The Act established within the Department of the Treasury the Federal Insurance Office (FIO) to monitor the insurance industry and its regulation. ${ }^{29}$ As it is constructed in Dodd-Frank, the FIO has no regulatory authority over any insurers. ${ }^{30}$ Expanding the power of the FIO to supplement or preempt state laws would help address the prospect that systemic risk in insurance could arise outside of individual systemically significant firms. ${ }^{31}$ Unlike the states, the FIO is reasonably well suited to identify and respond to emerging systemic risks in the insurance system given its global perspective and accountability to a national constituency. To limit the prospect that the FIO might be too aggressive in exercising this authority and aggrandizing its own power, the FIO's proposals to supplement or preempt state law might need to be approved by the Financial Stability Oversight Council (FSOC) - the same entity that Dodd-Frank empowers to identify individual insurance-focused financial companies that are systemically risky. ${ }^{32}$

This Article proceeds as follows. Part I provides an overview of US insurance regulation and the existing literature addressing the prospect that insurance can generate or contribute to systemic risk. It also describes the key structural changes to US insurance regulation that result from Dodd-Frank. Part II then argues that, as a result of common patterns in investment activities, product design, and risk-mitigation strategies, among other factors, entire segments of the insurance industry-in addition to individual "systemically important" insurance-focused firms-can play an important part in causing or exacerbating systemic risk. Finally, Part III explores the regulatory implications of these conclusions. It argues that the current system of state-based insurance regulation is ill suited to identify and manage systemic risk, and it consequently proposes empowering the FIO to supplement or preempt state law.

\footnotetext{
29 See Dodd-Frank $\S 313,124$ Stat at $1580-88$, codified at 31 USC $\S 313$.

30 See text accompanying notes 112-17.

31 See Part III.

32 See Dodd-Frank $\S 113,124$ Stat at 1398-1402, codified at 12 USC $\S 5323$.
} 


\section{AN OVERVIEW OF US INSURANCE REGULATION AND SYSTEMIC RISK}

Prior to 2008, conventional wisdom in regulatory and policy circles was that the insurance industry posed no meaningful risk to broader financial stability in the economy. ${ }^{33}$ Unlike the banking and securities sectors, the insurance industry had never been a primary, or even secondary, culprit in a broad financial panic. Insurers' prominent role in the global crisis of 2008 seemingly undermined this conventional wisdom. But since 2008, the dominant interpretation of these events-domestically, if not internationally ${ }^{34}$ - has been that they represent a narrowly confined exception to the preexisting conventional wisdom that insurance is not systemically risky. Thus, most academic and policy analyses of insurance and systemic risk in the United States argue that only a small category of nontraditional and noninsurance activities, such as those engaged in by AIG and the financial-guarantee insurers, can contribute to systemic risk. ${ }^{35}$ As a result, the primary change in the regulatory architecture of insurance since 2008 impacts only a small handful of insurance-focused financial companies that are deemed systemically significant. 36

This Part reviews these developments in insurance regulation and academic commentary on insurance and systemic risk since the crisis. Section A provides a brief overview of statebased insurance regulation and the related view that insurance does not pose systemic risk. Section B then describes the role of

\footnotetext{
33 This Article does not purport to define what should be meant by the "insurance industry" and "insurance." Instead, the Article's normative analysis relies on how those terms are currently viewed.

34 Globally, the regulatory response to systemic risk in insurance has been substantially more robust. Organizing through the International Association of Insurance Supervisors (IAIS) and the Financial Stability Board (FSB), global policymakers have begun to develop a coordinated and systematic framework for addressing the prospect of systemic risk in insurance. See, for example, International Association of Insurance Supervisors, Common Framework, online at http://www.iaisweb.org/Common-Framework--765 (visited Nov 3, 2014). As in the United States, this project involves identifying potential systemically risky insurers and subjecting them to enhanced prudential oversight. But unlike in the United States, global actors have paired this effort with attempts to develop a new macroprudential approach to insurance regulation that aims to identify and mitigate systemic risks in insurance that are not confined to individual institutions. See generally International Association of Insurance Supervisors, Macroprudential Policy and Surveillance in Insurance (IAIS Working Paper, July 18, 2013), online at www.iaisweb.org/view/element_href.cfm?src=1/19149.pdf (visited Nov 3, 2014).

35 See Part I.C.

36 See Part I.C.
} 
AIG, financial-guarantee insurers, and life insurers in the global financial crisis. Finally, Section $\mathrm{C}$ reviews the regulatory and academic responses to insurers' role in the crisis.

A. Pre-crisis US Insurance Regulation: State-Based Consumer Protection Regulation

Historically, insurance regulation has been the responsibility solely of the individual states rather than the federal government. ${ }^{37}$ Prior to 1944, this division of responsibilities was understood to be embedded in the US Constitution as a result of an old Supreme Court case holding that insurance is not "commerce" and hence cannot be regulated by Congress under the Commerce Clause. ${ }^{38}$ But in 1944, the Supreme Court reversed this holding, declaring that insurance was indeed "commerce" under the US Constitution. ${ }^{39}$ Shortly thereafter, largely as a result of state and industry lobbying, Congress passed the McCarranFerguson Act of 1945.40 The central provisions of that Act declared that the continued regulation of insurance by the states was in the public interest and that no federal law of general applicability should be interpreted to preempt state laws that regulate "the business of insurance." 41

Since passage of the McCarran-Ferguson Act, state insurance regulation has grown substantially in its scope and sophistication. Although individual states regulate the business of insurance conducted within their geographic boundaries, they coordinate extensively through an organization known as the NAIC. ${ }^{22}$ This coordination includes drafting model laws and regulations for adoption in the states, synchronizing enforcement efforts, and monitoring one another to ensure the sufficiency of

37 See Jonathan R. Macey and Geoffrey P. Miller, The McCarran-Ferguson Act of 1945: Reconceiving the Federal Role in Insurance Regulation, 68 NYU L Rev 13, 20-26 (1993) (examining the broad regulatory exemption for the "business of insurance"); Susan Randall, Insurance Regulation in the United States: Regulatory Federalism and the National Association of Insurance Commissioners, 26 Fla St U L Rev 625, 629-34 (1999) (showing that state control over insurance was unchallenged from the 1860 s until the New Deal).

38 Paul v Virginia, 75 US 168, 183 (1869) ("Issuing a policy of insurance is not a transaction of commerce.").

39 United States v South-Eastern Underwriters Association, 322 US 533, 553 (1944).

40 Pub L No 79-15, 59 Stat 33, codified at 15 USC $\S \S 1011-15$.

41 McCarran-Ferguson Act $\S 2$ (b), 15 USC $\S 1012(\mathrm{~b})$.

42 See Randall, 26 Fla St U L Rev at 635-36 (cited in note 37). 
each state's regulatory authority and resources. ${ }^{43}$ This last form of coordination is particularly important because it allows states to defer to one another when regulation of a single company by multiple states would be a waste of resources. ${ }^{44}$

The central goal of state insurance regulation is to protect consumers from various risks involved with purchasing insurance coverage. ${ }^{45}$ Accordingly, much state insurance regulation consists of standard consumer-protection rules: licensing requirements for insurers and agents, product and rate standards, prohibitions against unfair or misleading advertising, requirements for the fair payment of policyholders' claims, regulatoroperated complaint hotlines, and (sporadic) disclosure-oriented rules. ${ }^{46}$ Commentators occasionally distinguish these standard consumer-protection insurance rules from solvency regulation, which attempts to safeguard the financial strength of individual insurers. ${ }^{47}$ But the core goal of even solvency regulation has long been understood to be protecting consumers by ensuring that insurers have the financial capacity to pay policyholder claims when they become due. ${ }^{48}$

By contrast, state insurance regulation in general, and state solvency regulation in particular, is much less commonly justified based on a perceived need to ensure financial stability. The reason is that it has long been believed that the business of insurance is not systemically risky. ${ }^{49}$ In other words, according to conventional wisdom, there is little to no prospect that a shock to the insurance industry or an individual insurer could trigger a loss of economic value or confidence in a substantial segment of the financial system that is serious enough to have significant

43 See Kenneth S. Abraham, Insurance Law and Regulation: Cases and Materials 119-22 (Foundation 5th ed 2010).

44 See id at 120-21 (describing the NAIC's process of accreditation, which allows insurance regulators to defer to the solvency regulation of an insurer's state of domicile).

45 See Schwarcz, 94 Minn L Rev at 1735 (cited in note 19); Sharon Tennyson, Rethinking Consumer Protection Regulation in Insurance Markets *5 (Networks Financial Institute Policy Brief, Mar 2011), online at http://ssrn.com/abstract=1676418 (visited Nov 3, 2014) ("The primary motivation for consumer protection regulation in insurance is the idea that consumers in these markets are imperfectly informed about product characteristics.").

46 See Abraham, Insurance Law and Regulation at 118-19 (cited in note 43).

47 See, for example, Tennyson, Rethinking Consumer Protection at *1 n 2 (cited in note 45$)$.

48 See Schwarcz, 94 Minn L Rev at 1736 (cited in note 19).

49 See note 19. 
adverse effects on the real economy. ${ }^{50}$ There are several traditional explanations for this view.

The first and most important rationale for the view that insurance is not systemically risky is that insurers have only limited interconnections with the larger financial system. ${ }^{51}$ The interconnectedness of financial institutions is one of the central criteria by which most regulators and analysts assess systemic risk. ${ }^{52}$ In the insurance context, there are two ways to view interconnectedness. From one perspective, commentators view the insurance industry as unrelated to the banking industry and securities markets. ${ }^{53}$ Consistent with this view, insurance regulation traditionally has been completely separate from banking and securities regulation. ${ }^{54}$ Thus, under this view, even the failure of an insurer should not impact the larger financial system.

Another perspective on interconnectedness focuses on maturity transformation: the asset-liability mismatch that results

50 One of us has proposed a more specific definition of systemic risk, which is along the same lines. See Steven L. Schwarcz, Systemic Risk, 97 Georgetown L J 193, 204 (2008):

[S]ystemic risk: the risk that (i) an economic shock such as market or institutional failure triggers (through a panic or otherwise) either (X) the failure of a chain of markets or institutions or (Y) a chain of significant losses to financial institutions, (ii) resulting in increases in the cost of capital or decreases in its availability, often evidenced by substantial financial-market price volatility.

51 See Geneva Association, Cross Industry Analysis: 28 G-SIBs vs. 28 Insurers: Comparison of Systemic Risk Indicators *12 (Risk and Insurance Economics Working Paper, Feb 12, 2013), online at https://www.genevaassociation.org/media/472982/ga2013 -updated_cross\%20industry_analysis.pdf (visited Nov 3, 2014) (arguing that insurers are "much less interconnected" to other financial services than banks). But see National Association of Insurance Commissioners, Financial Institutions Exposure of U.S. Insurance Company Investments, Capital Markets Special Report (Center for Insurance Policy and Research), online at http://www.naic.org/capital_markets_archive/110520.htm (visited Nov 3, 2014) (commenting on connections between financial institutions and insurance companies through debt capital markets).

52 Along with size and substitutability, interconnectedness is one of three primary factors according to the FSB's criteria. See Financial Stability Board, Guidance to Assess the Systemic Importance of Financial Institutions, Markets and Instruments: Initial Considerations *9 (Report to G20 Finance Ministers and Governors, Oct 2009), online at https://www.bis.org/publ/othp07.pdf (visited Nov 3, 2014).

53 See, for example, Harrington, $76 \mathrm{~J}$ Risk \& Ins at 804 (cited in note 8) ("[I]nsurance markets are fundamentally different from banking. Sensible regulation ... should recognize the difference.").

54 The recent consolidation of insurance and other financial regulation in New York is evidence that this view is beginning to change. See New York State Department of Financial Services, History, online at http://www.dfs.ny.gov/about/history.htm (visited Nov 3, 2014). 
from the short-term funding of long-term projects. ${ }^{55}$ This mismatch-which interlinks short-term lenders with long-term borrowers and creates a liquidity risk that borrowers will be unable to repay their lenders - was at the core of the financial crisis and is the central rationale for banking regulation. ${ }^{56}$ Policymakers often assume that insurance is not systemically risky because, historically (and unlike banks and other financial institutions), insurers did not rely on maturity transformation for funding. Insurers' funding has traditionally stemmed principally from policyholders' payment of premiums, ${ }^{57}$ and that has been widely believed to be a long-term and stable funding source because policyholders are generally free to withdraw their funding only on the occurrence of contractually specified events, such as property destruction or death.58 Insurers have not historically depended substantially on other financial institutions to sustain, or even grow, their operations. ${ }^{59}$ This contrasts sharply with banking, in which the contractual ability of depositors to withdraw their funds at any time creates the prospect of a potentially contagious run on the banking system. ${ }^{60}$

55 See Huberto M. Ennis and Todd Keister, Bank Runs and Institutions: The Perils of Intervention, 99 Am Econ Rev 1588, 1590 (2009) ("Money market funds and other arrangements perform maturity transformation by investing in long-term assets while offering investors the ability to withdraw funds on demand.”).

56 See Gary Gorton and Andrew Metrick, Regulating the Shadow Banking System, 2010 Brookings Papers Econ Activity 261, 261-62 (discussing sale and repurchase agreements in the context of the 2008 financial crisis); Daniel M. Covitz, Nellie Liang, and Gustavo A. Suarez, The Evolution of a Financial Crisis: Panic in the Asset-Backed Commercial Paper Market *1 (Finance and Economics Discussion Series Working Paper No 2009-36, Aug 18, 2009), online at http://www.federalreserve.gov/pubs/feds/2009/ 200936/200936pap.pdf (visited Nov 3, 2014) (arguing that maturity transformation "played a central role in transforming concerns about the credit quality of mortgagerelated assets into a global financial crisis").

57 See Federal Insurance Office, Annual Report on the Insurance Industry *13 (June 2013), online at http://www.treasury.gov/initiatives/fio/reports-and-notices/Documents/ FIO\%20Annual\%20Report\%202013.pdf (visited Nov 3, 2014) (noting that approximately 75 percent of life- and health-insurance-sector revenue is generated from premiums).

58 See Cummins and Weiss, Systemic Risk and the U.S. Insurance Sector at *18 (cited in note 19).

59 See Kenneth A. Carow, Citicorp-Travelers Group Merger: Challenging Barriers between Banking and Insurance, $25 \mathrm{~J}$ Bank \& Fin 1551, 1554-57 (2001) (examining the still-significant regulatory barriers between banking and insurance at the end of the twentieth century); Kenneth A. Carow, The Wealth Effects of Allowing Bank Entry into the Insurance Industry, 68 J Risk \& Ins 129, 130-32 (2001) (examining the regulatory framework that made it difficult for banks to enter the insurance market until the late 1990s).

60 See Richard Scott Carnell, Jonathan R. Macey, and Geoffrey P. Miller, The Law of Banking and Financial Institutions 310 (Aspen 4th ed 2009). 
A second explanation for the view that insurance is not systemically risky derives from the substitutability of insurance, which is another criterion by which regulators and analysts assess systemic risk. Insurance is usually thought of as less essential to the operation of the macro-economy than other types of financial services, such as banking. In the life insurance context, many types of insurance have ready substitutes because they primarily function as an investment mechanism. ${ }^{61}$ And although life insurance is unique in its capacity to provide financial guarantees-particularly in the event of death-such guarantees, it is generally claimed, are not fundamental to the operation of the larger economy. ${ }^{62}$ Similar arguments are often made with respect to property and casualty insurance: disruptions in these markets, some suggest, may not noticeably impact the larger macro-economy. ${ }^{63}$ Indeed, the value of property and casualty insurance to large publicly owned companies is actually a matter of deep debate, with many arguing that those companies would be better off not purchasing such insurance. ${ }^{64}$ In any event, commentators often claim that any disruptions that do occur would likely be quite temporary given limited barriers to entry in the industry and the tendency of capital to migrate to insurance markets when they have become stressed. ${ }^{65}$

Size, which is another criterion by which regulators and analysts assess systemic risk, constitutes the third basis for the view that insurance is not systemically risky. By most measures, insurance is simply not as large as other segments of the financial system, particularly the banking system: insurers in the United States had about $\$ 7.3$ trillion of assets on their books in 2012 , whereas banks had $\$ 14.5$ trillion. ${ }^{66}$ Globally, insurers had

61 See Cummins and Weiss, Systemic Risk and the U.S. Insurance Sector at *32-33 (cited in note 19).

62 See, for example, id.

63 See generally, for example, Steven N. Weisbart and Robert P. Hartwig, Property/ Casualty Insurance and Systemic Risk (Insurance Information Institute Apr 2011), online at http://www.iii.org/sites/default/files/paper_Systemic\%20Risk_042011.pdf (visited Nov 3, 2014). This is significant because certain segments of the insurance system have indeed largely broken down in the past. The most notable examples are the socalled liability-insurance crises of the last several decades. See Tom Baker, The Medical Malpractice Myth 51-58 (Chicago 2005).

64 See, for example, Victor P. Goldberg, The Devil Made Me Do It: The Corporate Purchase of Insurance, 5 Rev L \& Econ 541, 542 (2009).

65 See, for example, Weiss, Systemic Risk and the U.S. Insurance Sector at *27-28 (cited in note 19).

66 FIO, Annual Report at *5 \& n 5 (cited in note 57). 
about $\$ 22.6$ trillion of assets in $2009 .{ }^{67} \mathrm{~A}$ substantial percentage of these assets are attributable to the life insurance industry, which serves the dual roles of protecting policyholders against risk and helping policyholders save and invest their assets. ${ }^{68}$

\section{B. The Global Financial Crisis and Insurance}

The financial crisis of 2008 poses obvious difficulties for the view that insurance is not systemically risky. This is most visible with respect to the dramatic and massive failure of AIG, a holding company with numerous subsidiaries engaging in a wide range of financial-services operations. ${ }^{69}$ Although many of these subsidiaries were indeed traditional insurance companies, AIG's problems resulted in large part from the activities of a company that was not licensed as an insurance company: AIG Financial Products (AIGFP). ${ }^{70}$

This AIG subsidiary issued an immense number of CDSs to numerous financial companies. From an economic perspective, CDSs act much like insurance: in exchange for a premium payment, the protection seller promises to pay the purchaser in the event of a default or other credit event on an underlying instrument. ${ }^{71}$ If, during the term of the CDS, a credit event or default becomes more likely to occur, then the protection seller is typically required to post additional collateral. ${ }^{72}$ Unlike traditional insurance, however, there is no need for the purchaser of a CDS to have an insurable interest in the underlying risk: a company can purchase a CDS on an underlying instrument even if it does not own that instrument. ${ }^{73}$

67 Bank for International Settlements, Fixed Income Strategies of Insurance Companies and Pension Funds *5 (Committee on the Global Financial System Working Paper No 44, July 2011), online at https://www.bis.org/publ/cgfs44.pdf (visited Nov 3, 2014).

68 See id at *5-8.

69 See Sjostrom, 66 Wash \& Lee L Rev at 945 (cited in note 1).

70 See id at $952-53$.

71 See Steven L. Schwarcz, Structured Finance: A Guide to the Principles of Asset Securitization $\S 10: 3.1$ at 14-16 (Practicing Law Institute 3d ed 2002); Hearing to Review the Role of Credit Derivatives in the U.S. Economy, before the House Committee on Agriculture, 110th Cong, 2d Sess 11 (2008) (statement of Erik R. Sirri, Director, Division of Trading and Markets, SEC).

72 See Sjostrom, 66 Wash \& Lee L Rev at 951 (cited in note 1).

73 See Arthur Kimball-Stanley, Insurance and Credit Default Swaps: Should Like Things Be Treated Alike?, 15 Conn Ins L J 241, 246-49 (2008) (discussing the arguments that CDSs are not insurance, including: (1) that CDSs lack an insurable interest requirement and indemnity requirement, (2) that the differing objectives of CDSs and insurance contracts justify differential treatment, and (3) that "CDS[s] are capital market products and not insurance") (quotation marks omitted). 
In the years leading up to 2008, AIGFP wrote a tremendous number of CDSs on mortgage-backed securities and similar financial instruments that were ultimately linked to homeowners' mortgage payments. ${ }^{74}$ For years, this subsidiary produced massive profits for AIG. ${ }^{75}$ But in the financial crisis, as markets started to indicate an increased risk of default on mortgagebacked securities and related financial instruments, AIG was forced to post increasing amounts of collateral and ultimately amassed staggering debts to its various counterparties. ${ }^{76}$ Concerned that AIG's failure to pay these debts to its counterparties could cause those counterparties to fail and trigger larger financial panic, the US government bailed out AIG by infusing capital that was used to pay off AIG's CDS counterparties in full. ${ }^{77}$

Although AIG's largest problems stemmed from its CDS business, it also experienced major stresses related to its securitieslending program, which more directly involved its insurance entities. Coordinating through a noninsurer AIG affiliate, AIG's insurers lent their securities to other firms on a short-term basis in exchange for fees. ${ }^{78}$ Borrowers of those securities were required to post cash collateral, but they were entitled to have that collateral returned to them if they returned the borrowed securities. ${ }^{79}$ As AIG began to experience financial turmoil, borrowers of the

74 At year-end 2007, AIGFP's CDS exposure was $\$ 533$ billion (net notional value). Harrington, 76 J Risk \& Ins at 790 (cited in note 8). Of this, $\$ 78$ billion (net notional value) were in multisector CDOs. Id at 791. AIGFP's multisector collateralized debt obligations (CDOs) were written on "super senior" tranches of asset-backed securities, which included pools of assets of residential mortgage-backed securities, commercial mortgagebacked securities, and CDOs. Of the $\$ 78$ billion, $\$ 61$ billion were exposed to subprime mortgages. Id; Sjostrom, 66 Wash \& Lee L Rev at 959 (cited in note 1).

75 A former AIGFP senior executive "characterized writing CDSs as 'gold' and 'free money' because AIGFP's risk models indicated that the underlying securities would never go into default." Sjostrom, 66 Wash \& Lee L Rev at 957 (cited in note 1).

76 As a consequence of the housing-market collapse, AIGFP ceased writing new multisector CDSs in 2005, and in 2007 and 2008, AIGFP was required to post additional collateral in compliance with its multisector CDO contracts. Harrington, $76 \mathrm{~J}$ Risk \& Ins at 791 (cited in note 8); Sjostrom, 66 Wash \& Lee L Rev at 960-61 (cited in note 1). By the end of August 2008, AIGFP posted about $\$ 20$ billion of additional collateral for its CDS portfolio. Harrington, $76 \mathrm{~J}$ Risk \& Ins at 790 (cited in note 8). And during the summer of 2008 , for example, AIGFP was required to post $\$ 6$ billion in additional collateral, equivalent to 34 percent of the cash and cash equivalents that AIG had available to meet the cash needs of its operations. Sjostrom, 66 Wash \& Lee L Rev at 960-61 (cited in note 1).

77 See Sjostrom, 66 Wash \& Lee L Rev at 963-75 (cited in note 1).

78 See National Association of Insurance Commissioners, Securities Lending in the Insurance Industry, Capital Markets Special Report (Center for Insurance Policy and Research), online at http://www.naic.org/capital_markets_archive/110708.htm (visited Nov 3, 2014); Harrington, 76 J Risk \& Ins at 791-93 (cited in note 8).

79 See Harrington, 76 J Risk \& Ins at 791 (cited in note 8). 
firm's securities availed themselves of this substitution option en masse, worried about their cash collateral not being returned by AIG. ${ }^{80}$ This, in turn, created dramatic and unanticipated liquidity needs for AIG, which had invested about 60 percent of the cash collateral it had received from securities borrowers in the very mortgage-backed securities whose value was precipitously declining. 81

AIG's bailout was not the only way in which insurers contributed to the 2008 financial crisis. In fact, financial-guarantee insurers also played a substantial role in the financial crisis. Financial-guarantee insurers are one type of monoline insurer: their business is in a single (that is, mono) line of insurance precisely because it is different in kind, and riskier, than other types of insurance. ${ }^{82}$ Originally, monoline financial-guarantee insurance covered the risk that municipal bonds would default. ${ }^{83}$ But in recent decades, financial-guarantee insurers expanded this coverage to the then-rapidly growing securitization markets, ${ }^{84}$ which offered numerous transactions to insure. ${ }^{85}$ Such coverage was generally purchased by the issuer of a covered security, which helped increase investor appetite for these instruments by limiting the financial consequences of default to the investor. ${ }^{86}$ In fact, financial-guarantee insurance supported

80 See id at $791-92$.

81 See American International Group: Examining What Went Wrong, Government Intervention, and Implications for Future Regulation, Hearing before the Senate Committee on Banking, Housing and Urban Affairs, 111th Cong, 1st Sess 56-59 (2009) ("Dinallo Testimony”) (statement of Eric Dinallo, Superintendent, New York State Insurance Department).

82 See Subcommittee on Financial Guarantee Instrumentation of the Committee on Developments in Business Financing, NAIC Model Act on Financial Guaranty Insurance: A Commentary, 43 Bus Law 717, 718 (1988) (noting that the NAIC chooses to require monoline insurance to handle increased risk).

83 See Wells Fargo, Deterioration of Monoline Insurance Companies and the Repercussions for Municipal Bonds *2-3 (Wells Fargo Funds Management 2008), online at http://www.wellsfargoadvantagefunds.com/pdf/whitepapers/monoline_insurance_muni _bonds.pdf (visited Nov 3, 2014).

84 See National Australia Bank, Monolines Deserve a Good Wrap *3 (National Australia Capital Markets Apr 2001), online at http://www.securitization.net/pdf/nabl _mono_0402.pdf (visited Nov 3, 2014) (explaining that financial-guarantee insurance policies issued by monolines offer "an unconditional and irrevocable guarantee" of the timely payment-according to their original maturities_of principal and interest to investors holding insured securities).

85 See Wells Fargo, Deterioration of Monoline Insurance Companies at *5 (cited in note 83) ("For the monolines, the lure of the [securitization] market was too great to ignore.").

86 See National Australia Bank, Monolines Deserve a Good Wrap at *13 (cited in note 84): 
much of the $\$ 330$ billion market for auction-rate securities (ARSs), which are long-term debt securities with short-term resetting interest rates issued by municipalities, museums, schools, and similar entities. ${ }^{87}$ In February 2008, the ARS market came to a halt because investors feared that monolines could not be counted on to pay their insurance. ${ }^{88}$ As the fear became contagious, investors started avoiding all ARSs, even those of strong issuers. 89

Like AIG, then, financial-guarantee insurers "insured" policyholders against the risk that financial instruments linked to the housing market would default. Unlike AIG, however, the companies that issued these products were explicitly regulated as insurers. ${ }^{90}$ At the same time, one of the primary reasons that financial-guarantee insurers are required to be monolines is that state regulators have long understood that this type of insurance is inherently riskier than other forms of insurance. ${ }^{91}$ By forcing insurers that sold this type of coverage to refrain from expanding into more traditional forms of insurance, state regulators may have limited the exposure of most of the insurance industry to this risk. ${ }^{92}$

Monolines adhere strictly to a no-loss underwriting strategy. ... The no-loss underwriting indicates that every deal needs to demonstrate full collectivity before the monoline will even consider wrapping the deal. As such the monolines implement stringent internal credit criteria. The no-loss underwriting strategy embraced by the monolines is tested against worst-case stress scenarios which help insure a zero rate of expected portfolio losses.

See also Standard \& Poor's, Global Bond Insurance 200610 (Standard \& Poor's 2006) (discussing the importance of the monolines' underwriting quality).

87 Christine Munroe, The Auction Rate Securities Market *16 (Securities Industry and Financial Markets Association Apr 2008), online at http://www.sifma.org/research/ item.aspx?id=21473 (visited Nov 3, 2014); The State of the Bond Insurance Industry, Hearing before the House Subcommittee on Capital Markets, Insurance, and Government Sponsored Enterprises of the House Committee on Financial Services, 110th Cong, 2d Sess 39 (2008) (statement of Erik R. Sirri, Director, Division of Trading and Markets, US SEC); Liz Rappaport and Kara Scannell, Credit Crunch: Auction-Rate Turmoil Draws Watchdogs' Scrutiny, Wall St J C2 (Feb 22, 2008).

88 Wells Fargo, Deterioration of Monoline Insurance at *8 (cited in note 83).

89 See Ted Phillips, Moody's Warns of Negative Impacts from Auction-Rate Securities, Bond Buyer 4 (Feb 21, 2008) (observing that failed auctions are "occurring in spite of the fact that the underlying credit quality of issuers remains strong") (quotation marks omitted).

90 See Dwight M. Jaffee, Monoline Regulations to Control the Systemic Risk Created by Investment Banks and GSEs, 9 BE J Econ Analysis \& Pol *10-11 (2009).

91 See id.

92 See id. 
Additionally, many traditional insurers-particularly life insurers-did indeed experience substantial capital deterioration during the financial crisis. ${ }^{93}$ This resulted from both sharp decreases in net income and dramatic increases in unrealized losses on investment assets in 2008.94 These capital shortfalls led insurers to apply for federal bailout funds, ${ }^{95}$ to seek changes to accounting rules in order to provide capital relief, 96 to sell insurance policies for less than their actual economic cost, ${ }^{97}$ and to receive capital infusions from their affiliate noninsurance companies. ${ }^{98}$ Life insurers with large portfolios of variable annuities with guaranteed lifetime benefits were particularly hard-hit, because they had to increase their reserves in response to declines in equity markets. ${ }^{99}$

Ultimately, as emphasized by a recent GAO report, both life insurers' capital cushions and their income rebounded quickly. By 2009 their capital levels and income had improved significantly, and by 2011 their investment portfolios had also largely rebounded. ${ }^{100}$ Moreover, throughout the financial crisis, very few life insurers failed: in 2008, consistent with historical trends, six life insurers were placed into receivership and three insurers were liquidated. ${ }^{101}$ Although 2009 saw increases in these numbers, rates of insurer failures fell below historical trends in 2010, when only four were placed into receivership and three were liquidated. ${ }^{102}$

\footnotetext{
93 See GAO Report at *10-17 (cited in note 7).

94 See id at *10 (noting that life insurers' net income decreased from $\$ 31.9$ billion in 2007 to a loss of $\$ 52.2$ billion in 2008 ); id at ${ }^{*} 11$ (noting that total unrealized losses amounted to $\$ 63.8$ billion in 2008 , and, as a result, total capital declined 6 percent in the life insurance industry in 2008).

95 See Harrington, 76 J Risk \& Ins at 788 (cited in note 8) ("Six insurers applied for and were authorized to receive TARP funds.").

96 See John Patrick Hunt, Credit Ratings in Insurance Regulation: The Missing Piece of Financial Reform, 68 Wash \& Lee L Rev 1667, 1689-94 (2011) (detailing regulators' strategy of capital relief, whereby they relaxed the capital requirements imposed on insurance companies).

97 See Ralph S.J. Koijen and Motohiro Yogo, The Cost of Financial Frictions for Life Insurers *2-3 (Chicago Booth Research Paper No 12-30, Apr 15, 2013), online at http://ssrn.com/abstract=2031993 (visited Nov 3, 2014).

98 See Gregory Niehaus, Managing Capital and Insolvency Risk via Internal Capital Market Transactions: The Case of Life Insurers *11-12 (working paper, Feb 2, 2014), online at http://papers.ssrn.com/sol3/papers.cfm?abstract_id=2429024 (visited Nov 3, 2014).

99 See GAO Report at *28-29 (cited in note 7).

100 See id at *12 (noting that life insurers' capital increased by 15 percent from 2008 to 2009).

101 Id at * 17 .

102 Id.
} 
C. The Post-crisis Regulatory Landscape: Federal Regulation of "Systemically Important" Nonbank Financial Companies

In 2010, Congress passed Dodd-Frank to reform financial regulation in light of the financial crisis. ${ }^{103}$ Not surprisingly, Dodd-Frank contained some reforms of state insurance regulation. The most important of these creates and empowers FSOC to designate insurance-focused financial companies, as well as other nonbank financial companies, as Systemically Important Financial Institutions (SIFIs). Such a designation subjects the SIFI to an additional layer of prudential supervision by the Fed, including enhanced capital requirements, regular stress testing, and various reporting and governance requirements. ${ }^{104}$ DoddFrank also subjects insurance-focused financial firms to federal scrutiny if they are themselves a savings-and-loan depository institution or own such an institution. ${ }^{105}$

FSOC has released complex regulations detailing its methodology for identifying nonbank financial companies as SIFIs. These rules establish an initial group of potential SIFIs by starting with firms with more than $\$ 50$ billion in total worldwide consolidated assets that also meet one of five quantitative tests relating to their derivative liabilities, aggregate debt, leverage, reliance on short-term debt, and status as a reference entity in CDSs. ${ }^{106}$ To date, FSOC has designated only three insurance-focused financial companies-AIG, Prudential, and MetLife-as SIFIs. ${ }^{107}$ Although AIG accepted this designation, both Prudential and MetLife have vigorously opposed it, arguing that, despite their size, they do not engage in any of the nontraditional insurance or noninsurance activities that create systemic risk. ${ }^{108}$ Prudential ultimately lost this appeal to FSOC and did not seek judicial review of the decision. ${ }^{109}$ Notably, both members of the council with expertise in insurance

103 Dodd-Frank, 124 Stat at 1376.

104 Dodd-Frank $\S 113,124$ Stat at 1398-1402, codified at 12 USC $\S 5323$ (setting criteria for when nonbank firms, including insurers, should be designated SIFIs).

105 Dodd-Frank $\S 312,124$ Stat at 1521-23, codified at 12 USC $\S 5412$.

106 See Financial Stability Oversight Council, Authority to Require Supervision and Regulation of Certain Nonbank Financial Companies, 77 Fed Reg 21637, 21661 (2012) (amending $12 \mathrm{CFR} \S 1310$ ).

107 See note 5 and accompanying text.

108 See Michael R. Crittenden and Leslie Scism, Global Finance: Prudential Hits Back on Risk Status, Wall St J C3 (July 22, 2013).

109 Sarah N. Lynch, Prudential Says It Will Not Appeal U.S. Council's Systemic Tag (Reuters Oct 18, 2013), online at http://www.reuters.com/article/2013/10/18/us-prudential -fsoc-idUSBRE99H11620131018 (visited Nov 3, 2014). 
dissented from this determination. ${ }^{110}$ Meanwhile, MetLife's challenge to its SIFI designation is ongoing as of October 2014. ${ }^{111}$

In addition to subjecting certain insurance-focused nonbank financial firms to federal regulation, Dodd-Frank created the FIO within the Treasury Department. ${ }^{112}$ The FIO has no regulatory authority over the insurance industry. ${ }^{113}$ Instead, the FIO's principal role is to serve as a federal monitor of the insurance industry and state regulation and to "coordinate Federal efforts and develop Federal policy on prudential aspects of international insurance matters." 114 Dodd-Frank directs the FIO to "monitor all aspects of the insurance industry, including identifying issues or gaps in the regulation of insurers that could contribute to a systemic crisis in the insurance industry or the United States financial system." 115 It also directs the FIO to "conduct a study and submit a report to Congress on how to modernize and improve the system of insurance regulation in the United States." 116 In December 2013, the FIO released this report, which concluded that state insurance regulation must occasionally be supplemented by federal intervention in specific areas in which state regulation proves unduly ineffective or inefficient. ${ }^{117}$

Although important, these reforms of insurance law and regulation leave the state-based system of insurance regulation essentially unchanged for all but the small number of insurancefocused financial firms that FSOC deems systemically significant or that own (or are) a savings-and-loan depository institution. Defenders of state insurance regulation argue that this is appropriate, emphasizing that AIGFP would never have been allowed to write the CDSs that it did if it had been regulated as an insurance company. ${ }^{118}$ Indeed, it was a federal statute-the Commodity Futures Modernization Act of 2000119_ that explicitly

\footnotetext{
110 See Zachary Tracer and Ian Katz, Prudential Financial Got Systemic Risk Label in 7-2 Vote, Bloomberg Personal Finance (Bloomberg Sept 20, 2013), online at http://www.bloomberg.com/news/2013-09-20/prudential-financial-got-u-s-systemic-risk-label -in-7-2-vote.html (visited Nov 3, 2014).

111 See note 5.

112 See notes $30-31$ and accompanying text.

113 See Dodd-Frank $\S 313,124$ Stat at 1580-88, codified at 31 USC $\S 313$.

114 Dodd-Frank $\S 313(\mathrm{c})(1)(\mathrm{E}), 124$ Stat at 1581, codified at 31 USC $\S 313(\mathrm{c})(1)(\mathrm{E})$.

115 Dodd-Frank $\S 313(\mathrm{c})(1)(\mathrm{A}), 124$ Stat at 1580, codified at 31 USC $\S 313(\mathrm{c})(1)(\mathrm{A})$.

116 Dodd-Frank $\S 313(\mathrm{p})(1), 124$ Stat at 1585, codified at 31 USC $\S 313(\mathrm{p})(1)$.

117 See FIO, Annual Report at *39-42 (cited in note 57) (discussing regulatory developments at the state and federal levels).

118 See, for example, Dinallo Testimony, 111th Cong, 1st Sess at 57 (cited in note 81).

119 Pub L No 106-554, 114 Stat 2763A-365.
} 
exempted derivatives such as CDSs from insurance regulation in the first place.120 And it was a federal agency-the Office of Thrift Supervision-that was the overarching regulator of AIG as a holding company. ${ }^{121}$ Moreover, while most proponents of state insurance regulation now acknowledge that regulation of financial-guarantee insurance was indeed flawed, ${ }^{122}$ they emphasize that the very fact that these insurers were required to be monolines limited the resulting damage. ${ }^{123}$ Finally, as described earlier, while many life insurers did indeed experience substantial capital shortfalls in the midst of the crisis, remarkably few insurers actually failed as a result. ${ }^{124}$

Closely related to these defenses of state insurance regulation in the midst of the crisis are various industry and academic assessments concluding that traditional insurance activities are not systemically risky, for many of the basic reasons outlined

120 See Saule T. Omarova, The Quiet Metamorphosis: How Derivatives Changed the "Business of Banking," 63 U Miami L Rev 1041, 1043 \& n 3 (2009) (noting that some critics blame the financial crisis on deregulatory legislation such as the Commodity Futures Modernization Act).

121 See Dinallo Testimony, 111th Cong, 1st Sess at 57 (cited in note 81); The Federal Insurance Office's Report on Modernizing Insurance Regulation, Hearing before Subcommittee on Housing and Insurance of the House Committee on Financial Services *2 ("Leonardi Testimony") (statement of Thomas B. Leonardi, Insurance Commissioner, State of Connecticut), online at http://financialservices.house.gov/uploadedfiles/hhrg-113 -ba04-wstate-tleonardi-20140204.pdf (visited Nov 3, 2014) (emphasizing that simply federalizing regulation does not improve matters, as federal regulators were responsible for failures in the 2008 crisis).

122 See, for example, Ana Carvajal, et al, The Perimeter of Financial Regulation *4 (International Monetary Fund Mar 26, 2009), online at https://www.imf.org/external/ pubs/ft/spn/2009/spn0907.pdf (visited Nov 3, 2014).

123 See, for example, Harrington, 76 J Risk \& Ins at 788 (cited in note 8). For arguments that monoline requirements limit damage, see Dwight Jaffee, Monoline Restrictions, with Applications to Mortgage Insurance and Title Insurance, 28 Rev Indust Org 83, 106 (2006) (claiming that a monoline requirement segregates risk, provides a useful structure for controlling conflicts of interest, and imposes higher capital requirements); Jaffee, 9 BE J Econ Analysis \& Pol at *10-11 (cited in note 90) (presenting monoline regulation as a way to deal with insurance risk).

124 See International Association of Insurance Supervisors, Insurance and Financial Stability *3 (Nov 2011), online at http://www.iaisweb.org/_temp/Insurance_and _financial_stability.pdf (visited Nov 3, 2014) ("The financial crisis of 2008/09 has shown that, in general, the insurance business model enabled the majority of insurers to withstand the financial crisis better than other financial institutions."); Michelle Brennan, Rodney A. Clark, and Michael J. Vine, What May Cause Insurance Companies to FailAnd How This Influences Our Criteria *4 (Standard \& Poor's RatingsDirect June 13, 2013), online at http://www.standardandpoors.com/spf/upload/Ratings_EMEA/2013 -06-13_WhatMayCauseInsuranceCompaniesToFail.pdf (visited Nov 3, 2014) ("Perhaps surprisingly, the global financial crisis that began in 2007 failed to trigger a wave of life and non-life insurer defaults among rated companies."). 
above. ${ }^{125}$ But even proponents of the view that insurance is not generally systemically risky admit that this conclusion does not apply to nontraditional insurance or noninsurance activities. ${ }^{126}$ It is precisely such activities, they claim, that characterize the roles of AIG and financial-guarantee insurers in the crisis. ${ }^{127}$ Both CDSs and financial-guarantee insurance for exotic structured securities are nontraditional or noninsurance products because they directly insure financial-market activities instead of property, mortality, longevity, or casualty risks. ${ }^{228}$ The specific type of securities-lending operations engaged in by AIG are also sometimes described as nontraditional.

Even after the crisis, insurers and their affiliates do, in fact, continue to participate in this set of activities that are labeled as nontraditional or noninsurance. ${ }^{129}$ For instance, insurers and their affiliates have continued writing substantial amounts of CDSs. One recent analysis concluded that insurers held approximately $\$ 270$ billion in outstanding CDSs globally in 2010.130 Domestically, the notional value of CDSs held by the insurance industry as of year-end 2011 was $\$ 45.1$ billion-a 6.8 percent increase from year-end $2010 .{ }^{131}$ It is unclear whether these numbers include the CDS activities of insurance entities' affiliates. According to at least one source, CDSs are written more often by insurer affiliates - as in the case of AIG-than by insurers directly. ${ }^{132}$ Life insurers also continue to be active lenders of securities.

\footnotetext{
125 See Part I.A.

126 See, for example, Harrington, 76 J Risk \& Ins at 788 (cited in note 8); Geneva Association, Systemic Risk in Insurance: An Analysis of Insurance and Financial Stability *3 (Risk and Insurance Economics Working Paper, Mar 2010), online at https://www.allianz.com/ v_1339671717000/media/responsibility/documents/geneva_association_report_on_systemic _risk_in_insurance.pdf (visited Nov 3, 2014).

127 See Geneva Association, Systemic Risk in Insurance at *20 (cited in note 126) (blaming insurance difficulties that arose during the crisis on "non-insurance activities").

128 See id at *58-63 (explaining the workings of financial-guarantee insurance and CDSs).

129 See Cummins and Weiss, Systemic Risk and the U.S. Insurance Sector at *37 (cited in note 19) ("[I]nsurers have remained active in the CDS market even after the AIG debacle.").

130 Id at *36-37.

131 National Association of Insurance Commissioners, An Update of the Insurance Industry's Derivatives Exposure, Capital Markets Special Report (Center for Insurance Policy Research), online at http://www.naic.org/capital_markets_archive/130109.htm (visited Nov 3, 2014).

132 See Nadège Jassaud and Sebastian Schich, Credit Default Swaps: Towards Tighter Regulation of the 'Shadow Insurance Sector,' in Patrick M. Liedtke and Jan Monkiewicz, eds, The Future of Insurance Regulation and Supervision: A Global Perspective 162, 170-72 (Palgrave Macmillan 2011).
} 
As of 2011 , for instance, the insurance industry had lent out $\$ 56$ billion under securities-lending agreements, with life insurers accounting for about 83 percent of this activity. ${ }^{133}$ By contrast, the market for financial-guarantee insurance has largely dissipated since the crisis. ${ }^{134}$

Additionally, new quantitative approaches that attempt to measure the systemic risk associated with particular segments of the economy suggest that there are important interconnections between the insurance industry and the rest of the financial system. ${ }^{135}$ Some of the most helpful such approaches attempt to identify correlations among historical stock prices or failure rates between the identified sector and other financial firms. ${ }^{136}$ Although the studies have produced mixed findings regarding the systemic risk associated with the insurance industry, many do find substantial interconnections between insurers and other types of financial institutions. ${ }^{137}$ But interpretation of these results has tended to depend on commentators' preexisting assessments of systemic risk in insurance. Thus, those who view traditional insurance activities as not being systemically risky attribute these results to insurers engaging in noninsurance or nontraditional activities, particularly the issuance of CDSs. ${ }^{138}$

133 NAIC, Securities Lending (cited in note 78).

134 See David S. Veno and Marc Cohen, U.S. Bond Insurers and the Financial Guarantee Sector Stand at a Crossroads *3 (Standard \& Poor's RatingsDirect Mar 19, 2014), online at http://www.nationalpfg.com/pdf/RatingAgencyReports/BI_Industry_Outlook _2014_3_19.pdf (visited Nov 3, 2014).

135 For an overview of this literature, see generally Dimitrios Bisias, et al, A Survey of Systemic Risk Analytics (Office of Financial Research Working Paper No 0001, Jan 5, 2012), online at http://www.treasury.gov/initiatives/wsr/ofr/Documents/OFRwp0001 _BisiasFloodLoValavanis_ASurveyOfSystemicRiskAnalytics.pdf (visited Nov 3, 2014).

136 See, for example, Viral V. Acharya, et al, Measuring Systemic Risk *17 (AFA 2011 Denver Meetings Working Paper, May 2010), online at http://papers.ssrn.com/ sol3/papers.cfm?abstract_id=1573171 (visited Nov 3, 2014) (developing marginal expected shortfall as an econometric measure based on "the average return on any given firm" during "the $5 \%$ worst days for the market").

137 See, for example, Monica Billio, et al, Econometric Measures of Connectedness and Systemic Risk in the Finance and Insurance Sectors, 104 J Fin Econ 535, 536 (2012) (finding increasing interconnectedness between financial institutions, including insurers, from 2001 to 2008 based on principal-components analysis and Granger-causality networks); Faisal Baluch, Stanley Mutenga, and Chris Parsons, Insurance, Systemic Risk and the Financial Crisis, 36 Geneva Papers 126, 134 (2011) (finding a significant correlation between banking and insurance stocks that increases during crisis, at least in Europe). See also Acharya, et al, Measuring Systemic Risk at *46 (cited in note 136) (finding that several insurers have high marginal expected shortfall).

138 See, for example, Billio, et al, 104 J Fin Econ at 536 (cited in note 137). 


\section{Systemic RISK IN INSURANCE RESULTING FROM CORRELATIONS AMONG FIRMS}

As Part I suggests, there is an emerging consensus that certain nontraditional forms of insurance and noninsurance activities, such as derivatives trading and financial-guarantee insurance, can contribute to systemic risk. In this Part, we argue that this is hardly the whole story. Instead, we suggest that the connections between the insurance industry and the larger financial system are deep, pervasive, and most importantly, constantly evolving. At the same time, we argue that the insurance industry itself is susceptible to tail end, catastrophic risk. Both of these potential precursors to systemic risk, we emphasize, can span individual companies and industry segments due to correlations in companies' products, risk-management techniques, investment strategies, and counterparties. As a result, systemic risk in the insurance industry can arise outside of an individual, too-big-to-fail firm.

Although certain of these correlations are shown to result, directly or indirectly, from government regulation, that does not make the correlations any less important or real, nor does it mean that less regulation is inherently better. Insurance is a critical financial industry that closely impacts consumers as policyholders; appropriate regulation is therefore necessary. Some of that regulation, inadvertently, can cause correlations in insurer behavior that can trigger systemic risk.

A. Interconnections between Insurers and the Larger Financial System

As described above, most commentators agree that the insurance industry can indeed have important linkages with the rest of the financial system to the extent that it engages in nontraditional or noninsurance activities. ${ }^{139}$ These are generally described to include the provision of financial-guarantee insurance; participation in derivatives markets, particularly as writers of credit default swaps; and, in some cases, securities-lending operations. At least in the latter two instances, the involvement of insurers and their affiliates in these nontraditional or noninsurance activities appears to continue to be significant. ${ }^{140}$ This Section, however, shows that this narrow set of nontraditional or

139 See text accompanying notes 124-33.

140 See text accompanying notes 128-33. 
noninsurance activities, which most clearly contributed to the last crisis, hardly exhausts the list of actual or potential interconnections between the insurance industry and the rest of the financial system.

1. The central connection between insurers and the rest of the financial system: insurers as owners of financial assets.

Most discussions of systemic risk in insurance overlook or downplay the most important linkage between the insurance sector and the rest of the financial system when it comes to assessing systemic risk. ${ }^{141}$ This linkage involves the industry's position as a major owner of financial assets. ${ }^{142}$ The business of insurance requires taking in policyholder premiums and, at some later point in time, paying those premiums back to policyholders if an insured event occurs. As a result, insurers-and life insurers, in particular-are among the most important investors in financial securities in the entire financial system. ${ }^{143}$ In fact, insurance companies are the largest institutional investors in debt securities-a market that is not only much larger than the market for equity securities but also the primary source of corporate financing. ${ }^{144}$ Insurers own approximately one-third of all

141 See, for example, Geneva Association, Systemic Risk in Insurance at *63 (cited in note 126) (concluding that typical insurance activities do not pose systemic risk); Cummins and Weiss, Systemic Risk at *31-39 (cited in note 19). But see Viral V. Acharya, et al, On the Financial Regulation of Insurance Companies *10 (NYU Stern School of Business Working Paper, 2009), online at http://web-docs.stern.nyu.edu/salomon/docs/ whitepaper.pdf (visited Nov 3, 2014) (arguing that insurers may be more systemically risky than commercial banks because of the interaction between insurer downgrades and investments); Robert F. Weber, Combating the Teleological Drift of Life Insurance Solvency Regulation: The Case for a Meta-risk Management Approach to Principles-Based Reserving, 8 Berkeley Bus L J 35, 53 (2011) (noting that the failure of a life insurer can trigger an asset fire sale, which can, in turn, "contribut[e] to other fire sales in other corners of the market, in which case the effects of an insolvent insurer's sell-off are likely to be unpredictable").

142 See Acharya, et al, Financial Regulation of Insurance Companies at *11 (cited in note 141); National Association of Insurance Commissioners, Update on Insurance Industry Investment Portfolio Asset Mixes (2013), online at http://www.naic.org/capital _markets_archive/130924.htm (visited Nov 3, 2014) (noting that insurance companies own assets worth more than $\$ 5$ trillion).

143 This role is particularly central for life insurance companies because the time period between payment of premiums and payout of claims is often quite long. See NAIC, Update on Insurance Industry (cited in note 142) (showing that life insurers held over 60 percent of the assets of the insurance industry in 2013).

144 See Samuel C. Weaver and J. Fred Weston, Strategic Financial Management: Applications of Corporate Finance 463-69 (Thomson 2008). See also Federal Reserve 
investment-grade bonds ${ }^{145}$ and, collectively, own almost twice as much in foreign, corporate, and municipal bonds than do banks. ${ }^{146}$ Insurers' holdings of corporate and foreign bonds exceed those of mutual funds and pension funds combined. ${ }^{147}$

Insurers' collective role as primary purchasers of financial securities might not be systemically noteworthy were it not for the fact that their investment decisions-including what types of securities to invest in and when to offload securities from their books-are, in many cases, deeply correlated with one another. ${ }^{148}$ There are several explanations for these correlations. First, the business models of many insurers tend to favor certain types of securities. For instance, because life insurers' liabilities are very long-term, such insurers tend to invest heavily in longterm assets to attempt to limit asset-liability mismatch. ${ }^{149}$ Second, insurers generally face a complex array of regulatory rules that impact their investment strategies, including risk-based capital rules and investment restrictions. ${ }^{150}$ Although these rules are designed to ensure that insurers are able to pay their obligations as they come due, the rules have the side effect of producing similarities in insurers' investment portfolios and decisions. ${ }^{151}$

Bank of San Francisco, What Are the Differences between Debt and Equity Markets? (Oct 2005), online at http://www.frbsf.org/education/publications/doctor-econ/2005/october/ debt-equity-market (visited Nov 3, 2014) (observing that although "the average person is much more aware of the equity (stock) market than of the debt market[,] [] the debt market is the much larger of the two").

145 See Paul Schultz, Corporate Bond Trading Costs: A Peek Behind the Curtain, 56 J Fin 677, 679 (2001).

146 See Hunt, 68 Wash \& Lee L Rev at 1669 (cited in note 96).

147 See Board of Governors of the Federal Reserve System, Financial Accounts of the United States: Flow of Funds, Balance Sheets, and Integrated Macroeconomic Accounts Historical Tables 2005-2013*94 (Mar 6, 2014), online at http://www.federalreserve.gov/ releases/z1/current/annuals/a2005-2013.pdf (visited Nov 3, 2014).

148 FSOC's decision designating Prudential as a SIFI acknowledged this very point, noting that "[t]he severity of the disruption caused by a forced liquidation of Prudential's assets could be amplified by the fact that the investment portfolios of many large insurance companies are composed of similar assets." Financial Stability Oversight Council, Basis for the Financial Stability Oversight Council's Final Determination Regarding Prudential Financial, Inc *3 (Sept 19, 2013), online at http://www.treasury.gov/initiatives/ fsoc/designations/Documents/Prudential\%20Financial\%20Inc.pdf (visited Nov 3, 2014).

149 See Anthony Saunders and Marcia Millon Cornett, Financial Institutions Management: A Risk Management Approach 83-84 (McGraw-Hill 7th ed 2011).

150 See Robert W. Klein, A Regulator's Introduction to the Insurance Industry 14049 (NAIC $2 \mathrm{~d}$ ed 2005).

151 See Whitehead, 96 Cornell L Rev at 346 (cited in note 16); Ayres and Mitts, Antiherding at *29 (cited in note 12 ) ("[R]educing insolvency-derived systemic risk necessitates prudential regulation aimed specifically at preventing conditional synchronization in financial institutions' outcomes.”). 
This is particularly true because these regulations often incorporate the ratings of private rating agencies, even after DoddFrank (which failed to alter the dependence of state insurance regulation on credit ratings). ${ }^{152}$ As a result, approximately 80 percent of bonds and preferred stocks held by insurers are tied to those credit ratings ${ }^{153}$ - a correlation that may well increase systemic risk. Third, insurers carefully safeguard their own financialstrength ratings, which are produced by a small handful of rating agencies that use similar techniques for assessing financial strength. ${ }^{154}$ These rating agencies themselves piggyback off of state risk-based capital ("RBC") rules, generally expecting carriers to maintain about 350 percent of required RBC. ${ }^{155}$

Insurers' coordination of their investment strategies, when combined with their massive collective role as investors, can have potentially destructive consequences from a systemic risk perspective. ${ }^{156}$ These potential systemic consequences can be divided into two broad categories: (a) market distortions associated with insurers' purchasing patterns for securities and (b) market distortions associated with insurers' sale of or sudden decreased demand for securities.

a) Market distortions from insurers' buying patterns. Insurers' coordinated investment activity can pose systemic risks by inflating asset bubbles and misallocating capital. ${ }^{157}$ In fact, emerging evidence suggests that life insurers played an important role in fueling the pre-crisis bubble in structured-finance

152 See Hunt, 68 Wash \& Lee L Rev at 1672-75 (cited in note 96) (discussing setting capital requirements based on asset credit rating). Thus, under the law of virtually every state, insurers are free to rely on ratings given by rating agencies for any bonds or preferred stocks in their portfolio.

153 Id at 1675. Because insurers are such large investors, rating agencies continue to enjoy what amounts to a special regulatory privilege, which arguably blunts their incentive to provide accurate ratings and may additionally increase systemic risk. See id at 1686.

154 See generally Steven W. Pottier and David W. Summers, Property-Liability Insurer Financial Strength Ratings: Differences across Rating Agencies, 66 J Risk \& Ins 621 (1999) (noting that while ratings agencies use distinct models for rating insurers, these agencies tend to focus on insurers' insolvency risk).

155 See Letter from H. Rodgin Cohen, Senior Chairman of Sullivan \& Cromwell to Ricardo Anzaldua, Executive Vice President and General Counsel of MetLife, Inc, *2 n 5 (May 20, 2013), online at http://www.federalreserve.gov/SECRS/2013/May/20130523/R-1438/R -1438_052313_111291_554506713029_1.pdf (visited Nov 3, 2014). See generally Letter from Members of Congress to Ben Bernanke, Chairman of the Board of Governors of the Federal Reserve System (Dec 11, 2012), online at http://www.federalreserve.gov/SECRS/2013/May/ 20130529/R-1442/R-1442_122112_110929_430365578957_1.pdf (visited Nov 3, 2014).

156 See Whitehead, 96 Cornell L Rev at 347-52 (cited in note 16).

157 See id at 327. 
securities linked to the housing market.158 By any measure, insurers are important purchasers of mortgage-backed securities: by 2007 , life insurers held approximately $\$ 470$ billion in these securities. ${ }^{159}$ Their current holdings of these mortgage-backed securities amount to almost $\$ 500$ billion. ${ }^{160}$

Not only are insurers major investors in structured securities linked to the housing market, but their demand for these securities increased by about 55 percent in the four years preceding the crisis. ${ }^{161}$ Life insurers' increased demand for these instruments was driven primarily by a subset of carriers that had issued products with embedded interest-rate guaranteesmostly guaranteed-annuity products. ${ }^{162}$ These carriers faced substantial unrealized losses during this period due to the unexpectedly low interest-rate environment. Seeking to offset these potential losses, these life insurers increased their holdings in mortgage-backed securities that offered higher returns than high-grade corporate bonds. Because regulators and rating agencies treated investments in mortgage-backed securities as largely riskless, insurers were able to increase their return while facing no consequences in terms of their RBC requirements or ratings. ${ }^{163}$

Life insurers in general, and particularly life insurers with heavy unrealized losses stemming from guaranteed annuities, were thus partially responsible for fueling the demand for structured-finance securities. ${ }^{164}$ In doing so, they played an important role in the 2008 global financial crisis. The explosion in

158 See Merrill, Nadauld, and Strahan, Final Demand at *18-19 (cited in note 22).

159 Id at *19. The authors report that this amounts to about 25 percent of the total market. Id at *2. But our own estimates suggest that this more likely represented approximately 5 percent, not 25 percent, of the total market. Nonetheless, $\$ 470$ billion is such a large amount of mortgage-backed securities that a coordinated sale by insurers could well trigger the beginning of a market-price collapse.

160 Robert McMenamin, What Do U.S. Life Insurers Invest In? *2 (Chicago Fed Letter No 309, Apr 2013), online at http://www.chicagofed.org/digital_assets/publications/ chicago_fed_letter/2013/cflapril2013_309.pdf (visited Nov 3, 2014).

161 Merrill, Nadauld, and Strahan, Final Demand at *19 (cited in note 22).

162 See id at * $15-16$.

163 See id at *30. This is made most evident by the fact that the life insurers that increased their exposures to these instruments were also the ones that were the most capital constrained. See id.

164 See id at *6 (cited in note 22) ("Together with the existing literature, our study suggests that the structured finance market was fueled both by supply-side distortions encouraging financial institutions to sell assets and demand-side distortions encouraging other financial institutions to buy those assets."); id at *29-30 ("Although issuance of ABS generated substantial fees for the banks, it is unlikely that issuance could have occurred at the rates observed without strong demand from final investors."). 
structured-finance securities linked to the housing market has been blamed for indirectly helping to stoke the pre-crisis housing bubble. ${ }^{165}$ Facing substantial demand to originate mortgages so that they could be packaged together and securitized, banks and other mortgage originators increasingly loosened credit standards, allowing more and more people to buy houses with loans that they ultimately could not afford. The resulting collapse in the housing market was the key trigger of the financial crisis writ large. ${ }^{166}$

Although insurers' role in inflating a bubble in mortgagebacked securities was clearly directly linked to the 2008 crisis, insurers' investments in corporate-debt markets raise potentially bigger systemic risks of capital market distortions. As with mortgage-backed securities, insurers in general, and particularly those that are capital constrained, appear to consistently "reach for yield" in their investments in corporate bonds. In other words, they invest in the riskiest-and highest yieldingcorporate debt within the categories of these securities that regulators and rating agencies define to be relatively low risk. ${ }^{167}$ The result is a broad distortion in the allocation of capital to the private sector, with corporations tending to issue riskier assets when insurance companies reach for yield.

Such distortions in capital market funding can directly amplify systemic risk by contributing to procyclical build-ups in the holding of high-yield, risky assets. Indeed, according to Fed Chairwoman Janet Yellen, "reaching for yield" was a core factor contributing to the build-up of highly leveraged forms of mortgage-backed securities that preceded the 2008 financial crisis. ${ }^{168}$ More generally, she has observed, the reaching-for-yield "dynamic has the potential to facilitate the emergence of financial imbalances ... [such as] investors holding assets which entail

165 See, for example, Merrill, Nadauld, and Strahan, Final Demand at *6 (cited in note 22).

166 See National Commission on the Causes of the Financial and Economic Crisis in the United States, The Financial Crisis Inquiry Report *113-15, 233-42 (2011), online at www.gpo.gov/fdsys/pkg/GPO-FCIC/pdf/GPO-FCIC.pdf (visited Nov 3, 2014).

167 See Bo Becker and Victoria Ivashina, Reaching for Yield in the Bond Market *2 (Harvard Business School Working Paper No 12-103, May 2012), online at http://dash .harvard.edu/bitstream/handle/1/9056486/12-103.pdf (visited Nov 3, 2014).

168 See id at *7, citing Janet Yellen, Remarks at the International Conference: Real and Financial Linkage and Monetary Policy, Bank of Japan (Federal Reserve June 1, 2011), online at http://www.federalreserve.gov/newsevents/speech/yellen20110601a.pdf (visited Nov 3, 2014); Raghuram G. Rajan, Fault Lines: How Hidden Fractures Still Threaten the World Economy (Princeton 2010). 
exposure to greater credit risk [while] not fully appreciat[ing], or demand[ing] proper compensation for, potential losses." 169 As a result, reaching for yield has significant potential to increase investment losses during a subsequent downturn. ${ }^{170}$

Insurers, in sum, play a crucial role in financial markets by virtue of the assets that they choose to purchase. These decisions are impacted by factors that often affect wide swaths of the industry, including regulatory capital rules, assessments of rating agencies, losses in commonly sold products, and perceived or actual constraints in available capital. And, collectively, these demand-side decisions can have systemic consequences by inflating asset bubbles and misallocating credit in crucial financial markets.

A crucial, and largely overlooked, point regarding these interconnections between insurers and the rest of the financial system is that insurers' potential to stoke systemic risk through their demand for securities need not involve mass failures or near failures of numerous insurers. A dominant narrative in the debates regarding insurance and systemic risk focuses on the fact that remarkably few insurers ultimately failed in connection with the global financial crisis. ${ }^{171}$ But as illustrated by life insurers' responses to unrealized losses on their guaranteedannuity products, even noncatastrophic losses to insurers can have systemically important consequences for other sectors of the financial system. ${ }^{172}$

b) Market distortions from insurers' selling patterns. Insurers' coordinated investment activities can also have potential systemic consequences due to sudden decreases in insurers' demand for certain securities or assets. For instance, insurers' coordinated investment activities can potentially ignite or exacerbate fire sales of assets, in which those assets sell well below their fundamental value. ${ }^{173}$ Such fire sales can play key roles in systemic

169 Yellen, Remarks at the International Conference at *2-3 (cited in note 168).

170 See Becker and Ivashina, Reaching for Yield at *29 (cited in note 167) ("[R] eaching for yield is not innocuous in terms of the ultimate risks taken on by insurance companies.").

171 See, for example, GAO Report at *17 (cited in note 7).

172 See text accompanying notes $160-64$.

173 In a fire sale, the price of an asset is temporarily depressed below its fundamental value. This is because the assets must be purchased by buyers with less familiarity with and demand for those assets. See Andrei Shleifer and Robert W. Vishny, Liquidation Values and Debt Capacity: A Market Equilibrium Approach, 47 J Fin 1343, 1356-58 (1992) (describing how assets could be sold to a buyer with a low fundamental valuation under certain market conditions). Indeed, the financial industry and members of Congress have 
crises by limiting firms' liquidity and creating uncertainty about firms' financial strength. ${ }^{174}$ Indeed, the inability of banks to offload or price toxic assets was the key reason for the failure or near failure of numerous investment banks, including Lehman Brothers. ${ }^{175}$ Alternatively, insurers' coordinated investment activities can conceivably result in sudden shortfalls in expected funding sources, producing costly and potentially systemically significant substitution effects among players in financial markets.

Consider emerging evidence that a subset of insurers was involved in the fire sale of mortgage-backed securities in 2008. As described above, insurers are substantial owners of mortgagebacked securities, and they had aggressively increased their holdings of these instruments in the years leading up to the crisis. In 2008, a subset of insurers that became capital constrained faced substantial pressures to offload these securities because they were subject to accounting rules requiring that they mark these assets to market value. ${ }^{176}$ In response, these carriers sold residential mortgage-backed securities (RMBSs) at substantially lower prices during this time period than did insurers not facing regulatory constraints. ${ }^{177}$ Moreover, the RMBSs that experienced the largest decline in credit quality during this period also sold for the largest discount from their fundamental value. ${ }^{178}$

blamed fire sales of mortgage-backed securities for contributing to the severity of the financial crisis. See Iman Anabtawi and Steven L. Schwarcz, Regulating Systemic Risk: Towards an Analytical Framework, 86 Notre Dame L Rev 1349, 1372-73 (2011) (“[F]irms subject to margin calls may be forced to engage in asset 'fire' sales, thereby depressing prices, requiring more forced sales, and depressing prices even further, thus creating a positive feedback effect.”).

174 See Anabtawi and Schwarcz, 86 Notre Dame L Rev at 1372-73 (cited in note 173).

175 See National Commission on the Causes of the Financial and Economic Crisis in the United States, Financial Crisis Inquiry Report at *324-25 (cited in note 166).

176 See Merrill, et al, Fire Sales in Distressed Mortgage-Backed Securities at *18 (cited in note 22).

177 See id at *22-23.

178 See id at *21-22 (finding that insurers subject to rules requiring mark-to-market accounting for RMBSs - property and casualty insurers, but not life insurers, until 2009were more likely to sell RMBSs during the financial crisis). Mark-to-market accounting rules remove the disincentive that firms would otherwise face from selling assets at a time when the firm believes that the market price does not reflect true asset value. See generally Andrew Ellul, et al, Mark-to-Market Accounting, Market Stress and Incentive Distortions, Rev Fin Reg Stud 6 (Summer 2013). The importance of mark-to-market accounting in contributing to fire sales by insurers is also supported by a second paper, by the same authors who studied fire sales in the corporate bond market and the importance of capital constraints. See Andrew Ellul, et al, Is Historical Cost Accounting a Panacea? Market Stress, Incentives Distortions, and Gains Trading *30-31 (NYU Working Paper, 2012). But see Steven L. Schwarcz, Regulating Complexity in Financial Markets, 87 
Although the evidence suggests that only a subset of insurers played a role in this fire sale, most insurers would likely have played a much larger role if it were not for two historically contingent facts. First, throughout much of the crisis, many insurers were fortuitously not required to use mark-to-market accounting for their portfolio of RMBSs, diminishing their incentive to sell these instruments. ${ }^{179}$ Second, in the midst of the crisis, the NAIC suddenly adopted a change in its RBC rules that substantially reduced the capital charges associated with RMBSs. ${ }^{180}$ Had either of these facts been different, insurers likely would have substantially exacerbated the fire sales in RMBSs and prolonged the severity of the crisis.

Insurers' capacity to trigger fire sales in capital markets is likely much stronger in corporate bond markets, in which insurers are the dominant investors among all financial institutions. Thus, one recent study offers compelling evidence that the downgrading of corporate bonds can prompt large numbers of insurers to sell the downgraded (or about-to-be downgraded) bonds in a coordinated fashion in order to avoid adverse regulatory or rating-agency consequences. ${ }^{181}$ Analyzing insurer behavior between 2001 and 2005, the study found that insurers facing comparatively large regulatory constraints were more likely than other insurers to immediately sell bonds that were downgraded from investment-grade status. ${ }^{182}$ This process of forced selling by regulatory-constrained firms caused the price of downgraded bonds to temporarily fall below their fundamental value. ${ }^{183}$ In particular, the study found that bonds' prices were more likely to depart from their fundamental value if the bonds were disproportionately held by regulatory-constrained firms. ${ }^{184}$

Some commentators have downplayed the prospect that insurers could trigger fire sales that could produce systemic

Wash U L Rev 211, 232-33 (2008) (discussing how regulation-motivated coordinated investor selling of securities can cause market collapses).

179 See Merrill, et al, Fire Sales in Distressed Mortgage-Backed Securities at *10 (cited in note 22).

180 See Hunt, 68 Wash \& Lee L Rev at 1676-80 (cited in note 96).

181 See Andrew Ellul, Chotibhak Jotikasthira, and Christian T. Lundblad, Regulatory Pressure and Fire Sales in the Corporate Bond Market, 101 J Fin Econ 596, 596-98 (2011) ("[F]orced selling is most likely to occur in the downgraded bonds that are held by regulatory-constrained insurers such as those that have low risk-based capital ratios.”).

182 See id at 605.

183 See id at 608. See also Anabtawi and Schwarcz, 86 Notre Dame L Rev at 135356 (cited in note 173) (explaining how an economic shock can become systemic).

184 See Ellul, Jotikasthira, and Lundblad, $101 \mathrm{~J}$ Fin at 618 (cited in note 181). 
consequences on the basis that there are low cross-holdings between insurers' and US banks' investment portfolios. ${ }^{185}$ But there are several problems with this view. First, as the crisis illustrated, insurers' coordinated actions with respect to even a relatively small component of their overall portfolio can disrupt markets. Second, even a fire sale of investment securities that were not directly held by banks could indirectly impact the value of banks' securities, such as by depressing larger segments of the securities markets. ${ }^{186}$ Third, one substantial source of this lack of overlap is attributable to privately placed bonds. ${ }^{187} \mathrm{Be}-$ cause no established secondary market for these types of securities exists, life insurers facing substantial liquidity needs would need to look to other asset categories. Fourth-and most importantly-the lack of substantial overlap between the portfolios of insurers and banks in the past does not mean there will not be substantial overlap in the future. Indeed, European insurers and banks currently have high cross-holdings of securities in sovereign bonds. ${ }^{188}$ That suggests not only that the systemic risk of insurer fire sales may be greater in Europe but also that the (arguably) currently low US cross-holdings could fluctuate and become greater.

Apart from the risk of fire sales, insurers' dominant role in financing US corporations raises the important potential risk that a massive disruption in insurance markets could substantially impact corporate financing. Insurers are the major investors in corporate debt; their holdings in these instruments equaled $\$ 1.5$ trillion in 2011.189 Given that corporations fund themselves much more through debt than equity, insurers are a crucial source of funding for US corporations. ${ }^{190}$ If insurers were forced to liquidate a substantial percentage of these holdings and were unable to maintain their long-sustained investment appetite for corporate debt, the results could be catastrophic. US corporations would have to either dramatically scale back their investments or find entirely new ways of funding their operations. This,

185 See, for example, Cummins and Weiss, Systemic Risk and Insurance at *31-32 (cited in note 19).

186 See id ("[B]anks and insurers are interconnected at least with respect to their susceptibility to common economic and financial shocks.").

187 See id at *19 (reporting that "[t]otal holdings of private placements represents $25.4 \%$ of life insurer bond portfolios").

188 See id at *26.

189 McMenamin, What Do U.S. Life Insurers Invest In? at *2 (cited in note 160).

190 See id. 
in turn, could trigger new and unpredictable consequences in volatile financial markets.

As above, insurers' capacity to distort financial markets by selling securities need not involve the ultimate failure of numerous carriers. Indeed, a key feature of fire sales is that those who trigger these sales may end up safe because they sell their assets at only a small discount. ${ }^{191}$ But just like the first people in line during a bank run, while the early participants in a fire sale may emerge relatively unscathed from a crisis, that does not mean that they were not instrumental in causing the crisis in the first place.

Although insurers need not fail en masse in order for their role as investors to stoke systemic risk, the converse is not true: substantial failures of a series of insurers could well disrupt the financial system by causing insurers to liquidate their portfolios or suspend their future investments. In many cases, an insurance company's failure can result in an immediate need for the company or its receiver to liquidate much of its portfolio. ${ }^{192}$ For instance, an insurance company could be required to quickly liquidate its portfolio if it failed due to a catastrophic event triggering an unmanageable number of claims, due to a failure of a reinsurer, or due to a run on products that permitted policyholders to withdraw funds or take out loans against their policies. ${ }^{193}$ If many insurers simultaneously experience this type of distresswhich is plausible given correlations in carriers' catastrophe exposures, product features, and reinsurance portfolios ${ }^{194}$ _it could trigger, or exacerbate, the types of distortions in capital markets that were witnessed in 2008.

Ultimately, there is strong, newly emerging evidence that numerous large life insurers played a major and under-appreciated role in the crisis of 2008 by virtue of their role as investors in

191 This effect is potentially explained by the greater incentive of closely regulated insurance companies to monitor assets for likely downgrades and sell assets at early signs of trouble, in effect causing the fire sale conditions that drop asset prices for other entities. See Ellul, Jotikasthira, and Lundblad, $101 \mathrm{~J}$ Fin Econ at 605 (cited in note 181).

192 But see Insurance Oversight and Legislative Proposals: Testimony before House Financial Services Subcommittee on Insurance Housing and Community Opportunity *9 (2011) (statement of the National Organization of Life and Health Insurance Guaranty Associations), online at https://www.nolhga.com/pressroom/articles/HFSCnolhgaTestimonyNov15 _2011.pdf (visited Nov 3, 2014) (arguing that insurers need less liquidity than banks).

193 See Part II.B.

194 See Part II.B. 
mortgage-backed securities. ${ }^{195}$ Of course, this evidence-like much about the financial crisis-is still uncertain and requires further research and assessment. But the point here is not just that insurers did, in fact, contribute to systemic risk in the most recent financial crisis through their role in stoking demand and contributing to fire sales in mortgage-backed securities. Rather, the larger point is that insurers, as massive investors that often act in a coordinated fashion with respect to their investment appetites and decisions, play an important role in the global financial system and in the potential accumulation of risk in that system.

2. Other potential linkages between insurers and the financial system.

Insurers' existing - and potential-connections to financial markets are hardly exhausted by their roles as investors. Various additional linkages exist. In some cases, the magnitude of these interconnections is not currently sufficient to raise systemic risks. In other cases, it is hard to know how to even measure the systemic implications of these connections. But both of these statements could almost certainly have been made about insurers' (and their affiliates') participation in CDSs ten years ago.

a) Insurance companies within complex financial-services groups. Insurance companies are increasingly part of conglomerate financial-services groups that provide an array of financial services, including banking and broker-dealer services. ${ }^{196}$ This creates the prospect that insurance company failures or distress could have serious consequences for noninsurance financial firms within the conglomerate group. Risks are much more likely to spread among corporate affiliates than among independent

195 See Merrill, et al, Fire Sales in Distressed Mortgage-Backed Securities at *29 (cited in note 22).

196 See Aerdt Houben and Mark Teunissen, The Systemicness of Insurance Companies: Cross-Border Aspects and Policy Implications, in Liedtke and Monkiewicz, eds, The Future of Insurance Regulation and Supervision 246, 254-59 (cited in note 132) (noting that "euro area insurers' financial assets roughly doubled in the [last] decade," and that many hedge funds and private equity groups manage assets owned by insurers). In part, the rationale for the rise in conglomeration is to exploit synergies between financial services and parents' businesses and also to take advantage of economies of scale and scope. Some firms also hope that business diversification will reduce their earnings fluctuations. See Gordon F. Boreham, The Rise of Non-bank Financial Conglomerates: A Major Trend in the Unfolding Financial Services Sector of the Canadian Economy, 9 Serv Indust J 90, 95 (1989). 
firms operating at arm's length. ${ }^{197}$ For instance, new empirical research shows that life insurers that are in financial distress tend to receive large capital contributions from other entities within their group and that this effect is concentrated in groups with a large number of affiliates. ${ }^{198}$ A related concern is that the holding company or other affiliates might be motivated to take risky actions, effectively supported by (and thus taking advantage of) government-backed guarantees of insurers. Although this concern is commonly cited in banking regulation, ${ }^{199}$ it is also a concern in the insurance industry, in which explicit state-guarantee funds-and potentially implicit federal guarantees in the event that state-guarantee funds fail-would seem to create a similar type of moral hazard among affiliates. 200

b) Insurance-linked securities. Insurers increasingly rely on financial markets to take on catastrophe risk. The most prominent example of this is catastrophe bonds, which are issued by insurers. ${ }^{201}$ Catastrophe bonds, like ordinary bonds, pay principal

197 See Richard J. Herring and Anthony M. Santomero, The Corporate Structure of Financial Conglomerates, 4 J Fin Serv Rsrch 471, 477-80 (1990).

198 See Niehaus, Managing Capital and Insolvency Risk at*21-27 (cited in note 98).

199 See, for example, Herring and Santomero, 4 J Fin Serv Rsrch at 480 (cited in note 197). US bank regulation attempts to address this concern most directly through $\S 23 \mathrm{~A}$ of the Federal Reserve Act, which restricts transactions, such as lending, between federally insured deposit-taking banks and their nonbank affiliates. See Saule T. Omarova, From Gramm-Leach-Bliley to Dodd-Frank: The Unfulfilled Promise of Section 23A of the Federal Reserve Act, 89 NC L Rev 1683, 1692-93 (2011).

200 To be sure, insurance regulations attempt to ring-fence insurance companies by requiring disclosure and approval of all material affiliated transactions. New state rules also attempt to enhance the power of regulators to demand information about insurers' affiliates and enhance group supervision by requiring that an Own Risk and Solvency Assessment be completed at the holding-company level. See Federal Insurance Office, How to Modernize and Improve the System of Insurance Regulation in the United States *34 (Department of the Treasury 2013), online at http://www.treasury.gov/ initiatives/fio/reports-and-notices/Documents/How\%20to\%20Modernize\%20and \%20Improve\%20the\%20System\%20of\%20Insurance\%20Regulation\%20in\%20the \%20United\%20States.pdf (visited Nov 3, 2014). But it is an open question whether these changes will be enough to reverse the clearly inadequate appreciation that state regulators had, prior to 2008, of risk to insurers posed by their affiliates. Moreover, all these approaches to ring-fencing are directed to protecting insurers from risks arising from their affiliates. None of the approaches is directed at the opposite threat: the prospect that distress might spread to an insurance affiliate from an insurer. See generally Steven L. Schwarcz, Ring-Fencing, 87 S Cal L Rev 69 (2013).

201 See J. David Cummins, CAT Bonds and Other Risk-Linked Securities: State of the Market and Recent Developments, 11 Risk Mgmt Ins Rev 23, 25-28 (2008). There also appears to be growing investor interest in debt securities operating as reinsurance of other insurable risks, including mortality and terrorism. See, for example, EdF's Pylon Marks First European Corporate Cat Bond, 834 Euroweek 47 (Dec 19, 2003) (describing the structure of an issued catastrophe bond insuring against losses from windstorm 
and interest upon maturity; however, if certain contractually specified catastrophic events-usually nonfinancial events, such as a hurricane-occur before the bond matures, the principal is forgiven. This makes catastrophe bonds unusually risky for investors, who can lose their entire investment if a catastrophe occurs. ${ }^{202}$ Investors are nonetheless willing to invest in catastrophe bonds, in part because they assume that these bonds provide investment diversification, displaying little or no correlation to the returns of shares and conventional bonds. ${ }^{203}$ Thus, the probability of a hurricane hitting a major urban area is not impacted by the prospect of instability in financial markets.

Currently, investment in catastrophe bonds-amounting to about $\$ 7$ billion per year-is not significant enough to be systemically risky. ${ }^{204}$ But analysts expect that the size of this market could increase substantially in coming years, and in recent years there already has been exponential growth in these types of financial instruments. ${ }^{205}$ Moreover, catastrophe bonds could well create important linkages between insurance and other financial markets because financial market risk and insuranceunderwriting risks are not always uncorrelated, as most assume. Various types of events could conceivably trigger instability simultaneously in financial markets and insurance markets. Consider, for instance, a global pandemic. Such an event would trigger payment on unprecedented numbers of life insurance policies. But it could also trigger financial panic by, for instance, triggering mass withdrawals of deposits or a collapse in stock

damage in France); Capital Markets Shield AXA from Extreme Mortality Risk, 978 Euroweek 62 (Nov 3, 2006) (summarizing the structure of a recent mortality bond that provides insurance against certain disasters such as a nuclear, chemical, or biological terrorist attack or a natural catastrophe in the United States, France, or Japan).

202 See Schwarcz, 94 Minn L Rev at 1785-86 (cited in note 19).

203 See id at 1786-87; Christopher M. Lewis and Peter O. Davis, Capital Market Instruments for Financing Catastrophe Risk: New Directions?, 17 J Ins Reg 110, 114 (1998); Angelika Schöchlin, Where's the Cat Going? Some Observations on Catastrophe Bonds, 14 J Applied Corp Fin 100, 102-03 (2002).

204 See Samantha Mortimer, Cat Bond Sales Finish 2012 near Record High, Property Casualty 360 (Jan 2, 2013), online at http://www.propertycasualty360.com/2013/ 01/02/cat-bond-sales-finish-2012-near-record-high (visited Nov 3, 2014).

205 See Rodd Zolkos, Catastrophe Bond Market Poised for Record Issuance in 2013: Report, Business Insurance (May 9, 2013), online at https://www.businessinsurance.com/ article/20130508/NEWS06/130509836 (visited Nov 3, 2014). See also Artemis, Catastrophe Bond Risk Premiums Slid Further by End of 2013, Artemis Blog (Feb 28, 2014), online at http://www.artemis.bm/blog/2014/02/28/catastrophe-bond-risk-premiums-slid -further-by-end-of-2013 (visited Nov 3, 2014) (explaining that 2013 saw record sales of catastrophe bonds and that premiums fell not because of a lack of demand or investor risk aversion but because of increased competition by insurers). 
markets due to sharp reductions in consumer consumption. And, of course, even otherwise-uncorrelated financial and underwriting risks might, over a large period of time, simultaneously occur simply as a matter of chance.

Another type of insurance-linked security that could potentially create important interconnections between insurance markets and other financial markets are life insurance-backed and annuity-backed securities. Financial firms have recently been purchasing rights under life insurance policies and annuities from policyholders. ${ }^{206}$ In some (and perhaps many) cases, policyholders have actually purchased life insurance or annuities after being contacted by a firm that has offered to fund this insurance purchase. ${ }^{207}$ However these rights are acquired, financial firms repackage the rights into securities that are then sold to investors. ${ }^{208}$ Just as with mortgage-backed securities in the financial crisis, there are various conceivable channels through which securities backed by these insurance rights could trigger systemic risk. For instance, widespread devaluation of these securities through insurer insolvencies or unanticipated and substantial changes in mortality rates could expose investors in these securities-as well as the financial firms that acquire, repackage, and sell the securities— to serious losses. ${ }^{209}$

\footnotetext{
206 See Jenny Anderson, New Exotic Investments Emerging on Wall Street: Packing Life Insurance Policies, despite Fallout from Mortgage Crisis, NY Times A1 (Sept 6, 2009):

The bankers plan to buy "life settlements," life insurance policies that ill and elderly people sell for cash $-\$ 400,000$ for a $\$ 1$ million policy, say, depending on the life expectancy of the insured person. Then they plan to "securitize" these policies, in Wall Street jargon, by packaging hundreds or thousands together into bonds. They will then resell those bonds to investors, like big pension funds, who will receive the payouts when people with the insurance die.... [S]ome in the industry predict the market could reach $\$ 500$ billion. . . Goldman Sachs has developed a tradable index of life settlements, enabling investors to bet on whether people will live longer than expected or die sooner than planned.

207 See James J. Avery Jr, Securities Backed by Life Settlements: Considerations for Institutional Investors $*_{2}$ (Prudential Financial Jan 2011), online at https://www.prudential.com/media/managed/Life_Settlements_Investing.pdf (visited Nov $3,2014)$.

208 See Anderson, New Exotic Investments Emerging on Wall Street at A24 (cited in note 206). As above, one of the draws of this type of financial product for investors is the perception that the risk of nonpayment is not substantially correlated with other forms of market-wide risk. See id (quoting Joshua Coval, professor of finance at Harvard Business School, who notes that "[t]hese assets do not have risks that are difficult to estimate and they are not, for the most part, exposed to broader economic risks").

209 See Avery, Securities Backed by Life Settlements at *2 (cited in note 207).
} 
c) Insurance as a prerequisite to credit. Insurance plays a crucial role in secured lending of all types. When lenders take a security interest or mortgage in collateral, they generally require the borrower to maintain insurance on the property throughout the duration of the loan. ${ }^{210}$ On a superficial level, the reason that lenders require such insurance is obvious: they want their collateral protected so that, in the event of default, they can look to that collateral for repayment. An important component of this explanation is that insurers are comparatively well situated relative to investors to measure and manage the risks associated with the prospect of damage to property. ${ }^{211}$ Indeed, this is the core business of property insurers.

If disruptions in property-insurance markets suddenly make unavailable property insurance of various types-such as homeowners, commercial property, auto collision and comprehensive, or commercial auto-the result could be substantial disruptions in the credit markets that rely on these forms of property to extend credit. ${ }^{212}$ Financial institutions that specialize in evaluating credit risk would not be equipped to merely lend without insurance on the collateral, as it would be nearly impossible for them to appropriately price this risk and manage the prospect of moral hazard. Using the vernacular of general frameworks on systemic risk, property insurance enjoys limited substitutability. ${ }^{213}$

d) Banks as guarantors of insurers. Another linkage between insurers and the larger financial system is that banks are becoming guarantors of insurers. As discussed below, life insurers increasingly have been using captive insurance-company subsidiaries to minimize the cost of complying with certain regulatory rules. ${ }^{214}$ To the extent that a captive reinsures a parent

210 See Kevin McKechnie, NAIC Hearing on Private Lender-Placed Insurance: Testimony Submitted on Behalf of the American Bankers Association *2 (2012), online at http:// www.naic.org/documents/committees_c_120809_public_hearing_lender_placed_insurance _testimony_mckechnie.pdf (visited Nov 3, 2014).

211 See Office of the Comptroller of the Currency, Risk Management and Insurance: Narrative and Procedures 3 (1990) (cautioning that companies that benefit from collateral insurance should assess the insurer's financial strength to protect themselves from insurer insolvency).

212 Professors J. David Cummins and Mary Weiss argue that small insurers would fill the gap and note that large corporations have many insurance substitutes. See Cummins and Weiss, Systemic Risk at *33 (cited note 19). But this depends on the size of the disruption in the underlying insurance markets.

213 See Part I.A.

214 See notes 299-302 and accompanying text (referring to this phenomenon as "shadow insurance"). 
life insurer's risk, the captive-which usually has a lower regulatory cost than its parent-is required (in lieu of the parent) to maintain capital reserves against that risk. ${ }^{215}$ The linkage with the larger financial system is that many states require that the captive's reinsurance obligation itself be financially supported. ${ }^{216}$ That support typically takes the form of a bank-issued letter of credit (LOC), ${ }^{217}$ which is a type of guarantee. ${ }^{218}$ Thus, if a captive is unable to pay its reinsurance obligation, then the beneficiary will draw down on the LOC, thereby requiring the bank to make that payment. ${ }^{219}$ In this way, banks have effectively become guarantors of life insurers' ability to pay their claims. ${ }^{220}$

\section{B. Vulnerabilities of the Insurance System to Tail End Events}

As noted above, insurers' various existing and potential linkages to the broader financial system have the potential to generate systemic risk even in the absence of widespread instability within the insurance industry itself. But, of course, many of the linkages between insurers and the rest of the financial system described above create the prospect of systemic risk only to the extent that the insurance industry itself is subject to the prospect of widespread instability. In many cases, moreover, the prospect that the linkages described above could trigger systemic risk depends on the risk that the insurance industry might face an acute crisis demanding the immediate liquidation of a substantial portion of its assets or the sudden cessation of its funding of other sectors. ${ }^{221}$ In this Section we suggest that the

\footnotetext{
215 See Ralph S.J. Koijen and Motohiro Yogo, Shadow Insurance *5 (NBER Working Paper No 19568, 2013), online at http://papers.ssrn.com/sol3/papers.cfm?abstract_id $=2320921$ (visited Nov 3, 2014).

216 See Captive and Special Purpose Vehicle (SPV) Use (E) Subgroup of the Financial Condition (E) Committee, Captives and Special Purpose Vehicles *12-13 (NAIC White Paper, June 6, 2013), online at http://www.naic.org/documents/committees_e_cspv _sg_2012_fall_nm_materials.pdf (visited Nov 3, 2014) (noting that all states have some, albeit lesser, requirements for captives).

217 See id at *4.

218 LOCs are agreements to make specified payments upon the presentation of documents that satisfy the negotiated conditions to payment. See UCC § 5-102(a)(10) (ALI 1995).

219 See NAIC Captives and Special Purpose Vehicle Use Subgroup, Captives and Special Purpose Vehicles at *14 (cited in note 216).

220 Although banks may have the right to seek reimbursement in the event of an LOC draw, that right is likely to be of limited value. But see id (discussing that right).

221 To be sure, many insurer failures do occur gradually, and the gradual unwinding of insurance companies is indeed the historical norm. See Insurance Oversight at *9 (cited in note 192); Cummins and Weiss, Systemic Risk at *17 (cited in note 19) (emphasizing
} 
insurance industry is indeed subject to such tail end risk and that, in many cases, these risks could create sudden and dramatic financial pressures on carriers.

\section{Catastrophe risk.}

Catastrophe risk arises when individual policyholder losses are correlated, resulting in large numbers of policyholder claims being made within a short period of time. ${ }^{222}$ Catastrophe risk is particularly relevant for systemic risk because it can result in a large percentage of an insurer's liabilities coming due immediately, producing very large liquidity needs. In many cases, insurers actively strive to limit their exposure to catastrophe risk precisely because they face substantial limitations in their ability to raise sufficient funds to pay unexpectedly large numbers of policyholder claims within a short period of time. ${ }^{223}$ Some of the most important mechanisms by which insurers attempt this include excluding catastrophe-risk exposure in their insurance policies, diversifying their exposure to catastrophes, and transferring some of their catastrophe risk to reinsurers. ${ }^{224}$

Despite these efforts to manage catastrophe risk, insurers' exposures to catastrophe risk can conceivably be quite large. ${ }^{225}$ Some insurers, for instance, do surprisingly little to mitigate catastrophe risks that have not occurred in the recent past (consistent with the availability heuristic, a commonly understood behavioral bias $\left.{ }^{226}\right)$. Consider, for example, the risk of a global

repeatedly that the resolution of insolvent insurers is gradual and does not typically require the immediate sale of a substantial portion of the entity's assets).

222 See Dwight M. Jaffee and Thomas Russell, Catastrophe Insurance, Capital Markets, and Uninsurable Risks, 64 J Risk \& Ins 205, 206 (1997).

223 See American Academy of Actuaries Catastrophe Management Work Group, Catastrophe Exposure and Insurance Industry Catastrophe Management Practices 7-15 (2001).

224 See id at 13.

225 See id at 21 (noting that catastrophe events pose a major risk of insolvency for insurers and other entities that aggregate catastrophe exposure in writing property insurance given that catastrophe events violate the conditions of probability and independence).

226 See Amos Tversky and Daniel Kahneman, Availability: A Heuristic for Judging Frequency and Probability, 5 Cognitive Psychology 207, 229 (1973) ("In thinking of [rare] events we often construct scenarios .... The plausibility of the scenarios that come to mind, or the difficulty in producing them, then serve as a clue to the likelihood of the event.") (emphasis omitted); Albert Phung, Behavioral Finance *15-17 (Investopedia 2011), online at http://i.investopedia.com/inv/pdf/tutorials/behavioralfinance.pdf (visited Nov 3, 2014) (explaining overreactions in stock prices to new information as attributable to availability bias). Recent research suggests that insurers, as well as consumers, are subject to various heuristics and biases. See Howard C. Kunruether, et al, Insurance and 
pandemic. In 1918, the Spanish Flu alone killed 20 to 40 million people within a single year.227 Unlike property-insurance policies, life insurance policies do not contain coverage exclusions for such a tail end event. Such an event could therefore result in massive additional claims against life insurers, which would owe immediate payment on their policies over and above their actuarially expected payments. ${ }^{228}$ Even if those claims don't imperil the insurers' own solvency, they could force insurers to simultaneously sell corporate bonds and other assets to raise cash, thereby triggering the type of fire sales or sudden contractions in corporate financing previously discussed. ${ }^{229}$

In other cases, insurers fail to limit their exposure to catastrophes because they do not even consider the possibility of the catastrophe occurring until it does. ${ }^{230}$ The best illustration of this point involves terrorism insurance. Prior to 9/11, commercial property-insurance policies did not contain any explicit exclusions for terrorism insurance and insurers did not even include this risk in their calculations of premiums. ${ }^{231}$ After 9/11, insurers insisted that the terrorism risk was so large and incalculable that they could not provide coverage at all, at least without an explicit federal backstop. ${ }^{232}$ Although the massive losses that insurers incurred in connection with $9 / 11$ did not substantially destabilize the industry, insurers' sudden and dramatic shift in their willingness to provide this coverage suggests that destabilization might well have occurred if events had transpired differently. Moreover, although it is rarely framed as such, the resulting Terrorism Risk Insurance Act of 2002233-which provided an

Behavioral Economics: Improving Decisions in the Most Misunderstood Industry 162 (Cambridge 2013).

227 Jeffery Taubenberger and David Morens, 1918 Influenza: The Mother of All Pandemics, 12 Emerging Infectious Diseases J 15, 15 (2006).

228 See Andrea Stracke and Winfried Heinen, Influenza Pandemic: The Impact on Insured Lives Life Insurance Portfolio (Society of Actuaries 2006), online at http://www.soa.org/library/newsletters/the-actuary-magazine/2006/june/pub-influenza-the -impact-on-an-insured-lives-life-insurance-portfolio.aspx (visited Nov 3, 2014).

229 See notes $173-78$ and accompanying text.

230 See Robert W. Klein, Regulation of Catastrophe Insurance: An Initial Overview *9 (Wharton Catastrophe Risk Project 1998), online at http://ibrarian.net/navon/ page.jsp?paperid=125681 (visited Nov 3, 2014) (explaining the lag of insurers in recognizing the potential impact and likelihood of major environmental catastrophes).

231 See Michelle Boardman, Known Unknowns: The Illusion of Terrorism Insurance, 93 Georgetown L J 783, 786 (2005).

232 See id at 787-88.

233 Pub L No 107-297, 116 Stat 2322 (2002), codified as amended in various sections of Title 15. 
immediate federal reinsurance backstop for terrorism riskessentially amounted to a federal bailout of the insurance industry: without any ex ante charge to carriers, the federal government now reinsures most commercial terrorism risk. ${ }^{234}$

It is obviously difficult, if not impossible, to predict what future catastrophes might occur that the industry has failed to adequately anticipate or guard against. One potential example, though, involves the burgeoning market for cyber insurance, which protects firms against various risks associated with data breaches, network damage, and cyber extortion. ${ }^{235}$ Interestingly, these policies generally do not contain any exclusions for cyberterrorism or mass and widespread cyber-instability. ${ }^{236}$ Given the increasing and unpredictable threat of cyberterrorism, it is not difficult to imagine that this type of risk exposure could produce massive correlated losses for a large segment of the insurance industry. Notably, such an event might well independently and simultaneously trigger wider financial instability.

\section{Reinsurance opacity and interconnectedness.}

Both property-casualty and life insurers rely extensively on reinsurance to mitigate their catastrophe risk. ${ }^{237}$ In 2011, for instance, US insurers ceded slightly more than $\$ 130$ billion in premiums to unaffiliated reinsurers, and approximately $\$ 110$

234 See Boardman, 93 Georgetown L J at 788-89 (cited in note 231).

235 See Deirdre Fernandes, More Firms Buying Insurance for Data Breaches: Companies Seek Added Protection, Boston Globe (Feb 17, 2014) online at http://www.bostonglobe.com/business/2014/02/17/more-companies-buying-insurance-against -hackers-and-privacy-breaches/9qYrvlhskcoPEs5b4ch3PP/story.html (visited Nov 3, 2014).

236 See generally Howard B. Epstein and Theodore A. Keyes, Insuring against Cyber Risks: Coverage, Exclusions, and Considerations, 249 NY L J 3 (May 22, 2013) (explaining that typical policy exceptions relate to intentionally tortious or illegal conduct in obtaining or handling cyber data).

237 See American Academy of Actuaries, Catastrophe Exposure at 15 (cited in note 223); Jaffee and Russell, 64 J Risk \& Ins at 215 (cited in note 222). Reinsurance can be structured in different ways. For instance, it can apply to a particular risk or to a contractually specified grouping of business (facultative or treaty), and it can shift risks to reinsurers on a proportional or nonproportional basis. Most commonly, reinsurers provide nonproportional treaty coverage, whereby the reinsurer agrees to bear the risk that losses will exceed a specified threshold on a grouping of business, up to a certain limit. One particularly important form of this type of reinsurance is excess-of-loss catastrophe coverage, whereby a reinsurer agrees to pay, up to a limit, for any claims against an insurer above the predetermined threshold if those claims are the result of a specified type of catastrophe. These policies may cover multiple catastrophes that take place within the policy period, reinstating the stated limit after each event. See Abraham, Insurance Law and Regulation at 781 (cited in note 43). 
billion in premiums to affiliated reinsurers. ${ }^{238}$ These amounts, of course, roughly approximate the expected recoverable catastrophe cost to reinsurers in a single given year: the potential recovery from reinsurers in the event of a massive catastrophic event or series of such events is obviously much larger.

At the same time that reinsurance reduces catastrophe risk for insurers, it also exposes insurers to new risks. The most obvious is counterparty risk arising from the possibility that reinsurers will be unable to follow through on their obligations. ${ }^{239}$ As with catastrophe risk, this could produce sudden and unanticipated liquidity needs for a primary carrier. But reinsurer failure could also undermine the availability of reinsurance coverage in the future, thus limiting the ability of insurers to write primary coverage. ${ }^{240}$ Additionally, reinsurer failure could impact insurers that hold reinsurer-issued securities in their investment portfolio. ${ }^{241}$

Reinsurer counterparty risk exposes the insurance industry to substantial vulnerabilities that, in many ways, resemble the counterparty risk that banks were exposed to in 2008 as a result of their derivative activities. First, the concentration of the reinsurance industry creates deep and substantial interconnections, such that the failure of one or two major reinsurers could simultaneously impact a substantial segment of the insurance industry

238 Cummins and Weiss, Systemic Risks at *13 (cited in note 19); Sojung Carol Park and Xiaoying Xie, Reinsurance and Systemic Risk: The Impact of Reinsurer Downgrading on Property-Casualty Insurers *7-8, 11 (China International Conference on Insurance and Risk Management Paper, 2012), online at http://www.ccirm.org/conference/ 2012/uploadfiles/A/III-A/1-ParkXie_Reinsurance\%20and\%20Systemic\%20Risk\%20The \%20Impact\%20of\%20Reinsurer\%20Downgrading\%20on\%20Property-Casualty

\%20Insurers_for_Qinghua2.pdf (visited Nov 3, 2014) (noting the increase in the market share of the top ten reinsurers from 35 percent in 1991 to 79 percent in 2009). Unfortunately, it is very difficult to tell how much reinsurance business with affiliates presents significant counterparty risk. In the case of life insurance, much of the reinsurance described above is shadow insurance, which we discuss elsewhere. See text accompanying notes 297-303. In the case of property-casualty insurance, many reinsurance arrangements with affiliates are a result of mergers-and-acquisitions activity, which does not operate economically in a manner similar to true reinsurance. See Park and Xie, Reinsurance and Systemic Risk at *11.

239 See Saunders and Cornett, Financial Institutions Management at 791-92 (cited in note 149); Cummins and Weiss, Systemic Risk at*13 (cited in note 19).

240 Without reinsurance, insurers would face drastically reduced capacity to write coverage because various tax, regulatory, and accounting factors limit their ability to hold capital to pay large numbers of roughly contemporaneous claims. See Jaffee and Russell, 64 J Risk \& Ins at 209-13 (cited in note 222).

241 But see Group of Thirty, Reinsurance and International Markets *5 (2006), online at http://www.group30.org/images/PDF/Reinsurance\%20and\%20International\%20Financial \%20Markets.pdf (visited Nov 3, 2014) (arguing that current life insurance exposure to reinsurance equities is too small to be significant in the event of a failure). 
at once. ${ }^{242}$ The reinsurance industry is extremely concentrated in a few massive firms, such as Swiss Re, Munich Re, and Berkshire Hathaway. ${ }^{243}$ In 2011, the most recent year for which data is available, for instance, five reinsurance groups provided approximately 67 percent of the world's reinsurance capacity. ${ }^{244}$ This concentration is particularly acute for life insurers, which place more than half of their nonaffiliate, reinsured risk with a single reinsurer and more than 90 percent of this risk with the top four reinsurers. ${ }^{245}$ Concentration in the reinsurance industry, moreover, is only trending upward due to mergers and acquisitions as well as organic growth. ${ }^{246}$

In addition to generating substantial interconnections within the insurance industry, reinsurer counterparty risk is highly opaque-as were the derivative markets that contributed to the financial crisis. ${ }^{247}$ Because reinsurance is an international business - the largest companies are located in Europe and Bermuda-there is a lack of uniformity about the ways in which these companies are regulated. ${ }^{248}$ This means not only that it is hard to know how much regulation directly limits default risk through tools such as reserve and capital requirements, but also that it is hard to acquire consistent financial data on different firms. As an important 2006 Group of Thirty ("G30") report explained, "[t]he risk information published by reinsurers varies significantly across firms in both frequency and scope" resulting

242 See Cummins and Weiss, Systemic Risk at *26 (cited in note 19) ("Reinsurance is the primary source of interconnectedness within the insurance industry."); Acharya, et al, Financial Regulation at *10 (cited in note 141) ("The reinsurance market increases the interconnectedness of the system exponentially and therefore might increase the systemic risk in the overall market" because of the "bilateral [relationship] in nature and [the lack of] adequate risk controls due to the opacity of bilateral markets.").

243 Although regulators have downplayed the risk posed by reinsurers, they admit that "high degrees of market concentration in the reinsurance sector could everything else being equal raise sector interconnectedness and limit the degree of substitutability ... [and thus] potentially raise intra-industry concerns." International Association of Insurance Supervisors, Reinsurance and Financial Stability 16 (2012).

244 A.M. Best, Reinsurers Resilient against Waves of Catastrophes, Economic Uncertainty *2 (Best's Special Report Apr 23, 2012), online at http://www.ambest.com/press/ 042303globalreinsurancereport.pdf (visited Nov 3, 2014).

245 Cummins and Weiss, Systemic Risk at *30 (cited in note 19).

246 See Park and Xie, Reinsurance and Systemic Risk at *7-8 (cited in note 238).

247 See id at *5 ("There is a serious lack of transparency associated with the risk of reinsurance transactions due to the international nature of reinsurance companies and lack of standardized prudential supervision.”).

248 See Marie-Louise Rossi and Nicholas Lowe, Regulating Reinsurance in the Global Market, 27 Geneva Papers Risk \& Ins 122, 127-29 (2002) (arguing that the reinsurance industry would benefit from more cohesive standards). 
in a "widespread perception that publicly available information about both the financial state and the risk profile of reinsurance companies is in many cases inadequate." ${ }^{249}$ As a result, private rating agencies are often understood to function as the "de facto regulator" of reinsurers. ${ }^{250}$

Complicating matters further is the fact that reinsurers are subject to a number of deeply complex risks. Because they rely extensively on catastrophe models to price coverage, reinsurers face a substantial amount of model risk. ${ }^{251}$ Yet the accuracy of catastrophe models is notoriously difficult to assess. ${ }^{252}$ As with all models, they rely on historical data to predict future risk, which (as reliance on historical housing data showed) is inherently risky. ${ }^{253}$ Additionally, reinsurers face their own form of counterparty risk due to their practice of purchasing reinsurance from other reinsurers (a process known as retrocession). ${ }^{254}$ This can result in retrocession spirals, wherein the failure of one reinsurer exposes other reinsurers to loss, potentially compromising their ability to pay as well. ${ }^{255}$

All of this makes it very difficult for anyone-including insurers, creditors of reinsurers, credit-rating agencies, regulators, and even reinsurers themselves - to accurately gauge reinsurerdefault risk. ${ }^{256}$ To be sure, two stress tests have found that, despite the various factors above, the failure of a major reinsurer would not substantially impact primary insurers. First, a stress test by the G30 conducted in 2006 concluded that the failure of a major reinsurer representing 20 percent of the global market would expose primary property-casualty insurers to losses of only 2 to 2.5 percent of global nonlife premiums. ${ }^{257}$ This conclusion

\footnotetext{
249 Group of Thirty, Reinsurance at *6, 13 (cited in note 241).

250 International Monetary Fund, Global Financial Stability Report: Risk Transfer and the Insurance Industry *102 (Apr 2014), online at http://www.imf.org/external/ pubs/ft/GFSR/2004/01/pdf/chp3.pdf (visited Nov 3, 2014).

251 See Schwarcz, 87 Wash U L Rev at 217 (cited in note 178).

252 See American Academy of Actuaries, Catastrophe Exposures at *18 (cited in note 223$)$.

253 See id (arguing that reliance on historical housing data caused borrowers to inaccurately understand the risk that they incurred).

254 See Cummins and Weiss, Systemic Risk at *26 (cited in note 19).

255 This possibility was vividly displayed in the 1990s when a chain of Lloyds syndicates failed as a result of having passed risk back and forth among themselves. See id at *27.

256 See Mark Flower, et al, Reinsurance Counterparty Credit Risks: Practical Suggestions for Pricing, Reserving and Capital Modeling *8-10 (July 2007), online at http://www.actuaries.org.uk/research-and-resources/documents/reinsurance-counterparty -credit-risks-practical-suggestions-pricing (visited Nov 3, 2014).

257 Group of Thirty, Reinsurance at *5 (cited in note 241 ).
} 
was driven by the fact that only 11 percent of such premiums are ceded to reinsurers worldwide. ${ }^{258}$ Meanwhile, the report speculated that any shortage of reinsurance would likely be short-lived given low market entry barriers and the capacity of remaining reinsurers to make up lost capacity. ${ }^{259}$ Second, a more recent, post-financial crisis analysis similarly concluded that the failure of a major reinsurer would not have a massive impact on primary insurers and would likely result in only a small number of primary carriers (approximately thirty) experiencing their own rating downgrades. 260

These simulations, however, do not establish that reinsurance cannot contribute to or cause systemic risk. Both simulations model the impact on primary insurers of an exogenous shock on reinsurers. But, of course, insurer and reinsurer results are deeply correlated: both insurers and reinsurers are impacted by underwriting cycles, financial market conditions, and catastrophic losses. Thus, any instability to insurers arising from reinsurance counterparty risk would almost certainly be paired with other sources of stress to insurers. Additionally, both simulations implicitly assume that the instability of one reinsurer would not be correlated with instability of other reinsurers. ${ }^{261}$ This too may not be a realistic assumption: even ignoring that reinsurers rely on similar risk models and are exposed to similar catastrophe risks and market conditions, ${ }^{262}$ the industry is subject to the prospect of correlated instability among reinsurers due to the prospect of a retrocession spiral.

Much more importantly, these analyses assess the vulnerability of the reinsurance system at a specific point in time. Our point here, and the relevant point for assessing systemic risk (at least from the perspective of designing an overarching regulatory architecture), is that the structure of the underlying system is capable of becoming systemically vulnerable in the future. Even if earlier stress tests are correct that the reinsurance industry poses little risk to the larger insurance system, core features of

\footnotetext{
258 Id.

259 See id.

260 See Park and Xie, Reinsurance and Systemic Risk at *23 (cited in note 238).

261 See Group of Thirty, Reinsurance at *38 (cited in note 241) (assuming that the failure of even a large reinsurer with 20 percent market share would not be catastrophic because 20 percent is not a large enough share, which implies that the failure would not be correlated); Park and Xie, Reinsurance and Systemic Risk at *26-27 (cited in note 238).

262 See Schwarcz, 87 Wash U L Rev at 227 (cited in note 178) (referencing model failure that led to a pricing panic in the $\mathrm{CDO}$ and asset-backed-security financial markets).
} 
the structure of that industry-including its concentration, lack of consistent regulation, and second-order linkages-make it intrinsically susceptible to the possibility of such a collapse in the future.

\section{Insurers' guarantees against financial risk.}

A substantial percentage of life insurers' premiums are currently attributable to products that are principally investment oriented and that guarantee contractually specified investment returns to policyholders. ${ }^{263}$ Examples include variable annuities, ${ }^{264}$ fixed-indexed annuities, ${ }^{265}$ and guaranteed-investment contracts. ${ }^{266}$ Perhaps the most stark example of this-which illustrates how insurance products can morph into financialguarantee products - is the contingent deferred annuity (CDA), wherein an insurer guarantees that an investment vehicle chosen by the policyholder and maintained independently of the insurer (such as a 401(k) or mutual fund) will yield contractually specified payments for the remainder of the policyholder's lifetime.267

Insurance products incorporating investment guarantees create the prospect that prolonged and unanticipated changes in financial markets could place a substantial strain on numerous life insurance companies at the same time. For instance, as apparently occurred from 2003-2007, unanticipated low interest rates can cause substantial losses on products that contain

263 See Insurance Information Institute, Annuities (2014), online at http://www.iii.org/ article/annuities (visited Nov 3, 2014) ("Measured by premiums written, annuities are the largest life/health product line.").

264 For recent data on variable annuity sales, see Insured Retirement Institute, Fixed Annuity Sales Push Industry-Wide Sales to Highest Level in Two Years (Dec 5, 2013), online at http://www.irionline.org/research/research-detail-view/fixed-annuity-sales -push-industry-wide-sales-to-highest-level-in-two-years (visited Nov 3, 2014) (stating that total variable annuity assets topped $\$ 1.7$ trillion in 2013 and that sales averaged over $\$ 35$ billion a quarter).

265 For similar data on fixed annuity sales, including average quarterly sales in 2013 that topped $\$ 17$ billion, see id.

266 See id.

267 See NAIC Contingent Deferred Annuity Subgroup, Report of the CDA Subgroup to the Life Insurance and Annuities Committee Members (Feb 22, 2012). See also Letter from Birny Birnbaum, Executive Director, Center for Economic Justice, to Ted Nickel, Chair, NAIC CDA Subgroup *2 (Oct 8, 2012), online at http://www.naic.org/documents/ committees_a_contingent_deferred_annuity_wg_2012_fall_nm_materials.pdf (visited Nov 3,2014 ) (voicing the concern that adverse market conditions could result in significant financial loss for CDAs because exhaustion of holders' financial assets would trigger massive simultaneous claims). 
embedded interest-rate guarantees. ${ }^{268}$ Similarly, a sudden and prolonged decrease in equity, real estate, or bond markets could simultaneously place substantial pressure on insurers with large portfolios of CDAs, guaranteed-investment contracts, or traditional annuities with lifetime guarantees. ${ }^{269}$ It is worth remembering in this context that, while recovery from the 2008 crisis has in many ways been slow, the crisis was characterized by a robust and relatively quick rebound in the value of most financial instruments, particularly equity markets. ${ }^{270}$ But this need not always be true: some financial market collapses are characterized by a long and sustained drop in the value of financial instruments. 271

The widespread failure of investment guarantees could conceivably produce broader consequences: reduced retirement savings could trigger unanticipated mortgage and credit card defaults, a sudden uptick in the need for social services, or labor market distortions as newly retired individuals attempt to reenter the job market. ${ }^{272}$

\section{Policyholder runs and guarantee-fund structure.}

The insurance system may also be vulnerable to policyholder runs, a risk that could well increase in the future depending on developments in insurance-policy design. In many types of insurance, insureds "have a right to demand payment [only] on the occurrence of a contractually specified event. This minimizes

268 See Merrill, Fire Sales in Distressed Mortgage-Backed Securities at *18 (cited in note 22). Of course, insurers are exposed to a variety of potential risks associated with interest rates, given the long-term nature of all life insurance products. See generally Kyal Berends, et al, The Sensitivity of Life Insurance Firms to Interest Rate Changes, 37 Econ Persp 43 (2013).

269 For instance, in 1991 six major life insurers, each with over $\$ 4$ billion in assets, failed as a result of their common exposures to commercial real estate and junk bonds. See Scott Harrington, Policyholder Runs, Life Insurance Company Failures, and Insurance Solvency Regulation, 15 Cato Rev Bus \& Govt 27, 27 (1992).

270 See GAO Report at *11-12 (cited in note 7).

271 For a discussion of how the stock market crash and uncertainty in the value of financial products led to drastic declines in consumer spending and were exacerbated by instability in the US banking system, see Christina D. Romer, The Nation in Depression, 7 J Econ Persp 19, 29-33 (1993).

272 Various reports have emphasized that the global financial crisis taught that the financial distress of individuals can rather easily morph into financial distress for the financial system. See, for example, National Commission on the Causes of the Financial and Economic Crisis in the United States, Financial Crisis Inquiry Report at *213-21 (cited in note 166) (describing how the rising default rate of individual homeowners snowballed into a global financial crisis). 
the risk of a 'run' on an insurer." 273 But this is not true of many life insurance products. Life insurance and annuity products often allow policyholders to cash out their policies. ${ }^{274}$ For some products, such as deferred annuities, policyholders often have the right to withdraw their funds with no penalties, at least after an initial contractually specified period.275 For other products, such as whole and universal life insurance, policyholder withdrawals from cash-value accumulation often involve the payment of penalties to the insurer. ${ }^{276}$ Apart from cash withdrawals, policyholders often enjoy contractual rights to take out loans against their life insurance policies, which may come along with much smaller fees and do not require forfeiting insurance coverage.

These features of many life insurance policies mean that policyholders who become concerned about their carriers' solvency may well demand withdrawals or policy loans, producing a downward spiral analogous to those found in classical bank runs, in which some bank depositors panic, converging on the bank in a "grab race" to withdraw their monies first. ${ }^{277}$ Although this risk is well understood, it has historically been downplayed because of the fees associated with many forms of policyholder withdrawal. ${ }^{278}$ But there is indeed historical precedent for a run

273 Schwarcz, 94 Minn L Rev at 1753 (cited in note 19).

274 See Weber, 8 Berkeley Bus L J at 47 (cited in note 141). For instance, in its decision designating Prudential as a SIFI, FSOC noted that:

Although Prudential does not substantially depend on short-term funding, and its life insurance and annuity products are generally considered to be relatively long-term liabilities, a substantial portion of the liabilities in the U.S. general account are available for discretionary withdrawal with little or no penalty and therefore could, in practice, have characteristics of short term liabilities. Policyholders in Prudential's separate account and international insurance business are also able to surrender policies for significant cash values on short notice.

FSOC, Final Determination Regarding Prudential at *8 (cited in note 148).

275 See FSOC, Final Determination Regarding Prudential at *8 (cited in note 148).

276 See id at ${ }^{*} 2-3$.

277 See Jonathan R. Macey and Geoffrey P. Miller, Bank Failures, Risk Monitoring, and the Market for Bank Control, 88 Colum L Rev 1153, 1156 (1988) (linking bank runs and depositor collective action problems).

278 See, for example, Scott E. Harrington, Capital Adequacy in Insurance and Reinsurance, in Scott, ed, Capital Adequacy beyond Basel 87, 93 (cited in note 19) (noting that there is a smaller risk of runs in insurance than in banks); Guillaume Plantin and JeanCharles Rochet, When Insurers Go Bust: An Economic Analysis of the Role and Design of Prudential Regulation 47-49, 90-93 (Princeton 2007) (discussing how deductible fees associated with insurance-policy withdrawals minimize moral hazards and corresponding risks that remain present in the withdrawal of demandable bank deposits, and finding no evidence of a contagion effect in insurance). 
on a life insurance company: in 1991, policyholders withdrew over $\$ 3$ billion from Executive Life in the year prior to its failure. ${ }^{279}$ Although this run was more a product of Executive Life's tenuous financial position than the cause of its tenuous position, it did indeed have the effect of forcing Executive Life to liquidate a substantial percentage of its portfolio. 280

Moreover, the risk of a run on a life insurer is likely increasing. First, life settlement companies have increasingly offered policyholders the option of selling their policies to investors for much larger sums than the surrender value (the opposite side of the insurance-backed securities market described above). ${ }^{281}$ As this industry becomes more and more sophisticated and prevalent, insurers will increasingly face market pressures to allow policyholders to cash out of their policies at amounts approaching their net present value. ${ }^{282}$ This is because insurers decidedly do not want policyholders selling their policies to investorsunlike policyholders, investors never let policies lapse. ${ }^{283}$

Second, life insurers are increasingly making payouts to policyholders by issuing retained-asset accounts, which operate almost exactly like bank accounts: policyholders can withdraw their funds from these accounts at any time, with no fee, simply by using instruments that function almost identically to checks. ${ }^{284}$ Unlike bank accounts, however, these accounts are not backed by FDIC insurance. A recent survey by the Texas Department of Insurance of 160 life insurers found open retained-asset

\footnotetext{
279 See Harrington, 15 Cato Rev Bus \& Gov at 29 (cited in note 269).

280 See id. The failure of Executive Life was a major contributor to the states reforming their RBC regimes. See Bill Coffin, et al, The Complete ELNY Saga: 21 Years of Mismanagement, Corruption, Broken Promises and Shattered Lives (LifeHealthPro 2013), online at http://www.lifehealthpro.com/pages/the-complete-elny-saga.php (visited Nov 3, 2014). But while the reform of the state RBC regime might well limit the risk of a failure such as that of Executive Life, it does not alter the fundamental point that insurers can indeed be susceptible to policyholder runs when insurers' policyholders lose confidence in their long-term solvency.

281 See Nadine Gatzert, The Secondary Market for Life Insurance in the United Kingdom, Germany, and the United States: Comparison and Overview, 13 Risk Mgmt \& Ins Rev 279, 287-91 (2010).

282 See id at 296.

283 See Eryn Mathews, STOLI on the Rocks: Why States Should Eliminate the Abusive Practice of Stranger-Owned Life Insurance, 14 Conn Ins L J 521, 530 (2007).

284 National Association of Insurance Commissioners, Retained Asset Accounts and Life Insurance: What Consumers Need to Know about Life Insurance Benefit Payment Options (Aug 2010), online at http://www.naic.org/documents/consumer_alert_raa.htm (visited Nov 3, 2014).
} 
accounts totaling $\$ 2.3$ billion for policyholders living in Texas alone. ${ }^{285}$

One objection to the prospect that life insurers could be subject to a run by policyholders is that many life insurers contractually maintain the right to delay payouts on policies with immediate withdrawal benefits. But as FSOC emphasized in rejecting this argument in the context of designating Prudential as a SIFI, "the company could have strong disincentives to invoke" a contractual withdrawal right "because of the negative signal invoking such a deferral could provide to counterparties, investors, and policyholders." 286 This rationale, of course, applies with equal force to other insurers.

While there is limited historical evidence of policyholder runs at one insurer triggering defaults at other insurers, the existence of state-by-state, rather than federal, guarantees of policyholder payment increases the risk that a run on one institution could cause runs at other institutions. This is because stateguarantee funds are much less reliable and complete than FDIC insurance. ${ }^{287}$ State-guarantee funds are not generally prefunded, they limit payouts to amounts that are often well below the face value of insurance policies, they are subject to a per-claimant limit, and they are not (explicitly) backed by the federal government. ${ }^{288}$ Moreover, state-guarantee funds are premised on the capacity of nontroubled insurers to cover the obligations of failing insurers. ${ }^{289} \mathrm{As}$ such, their capacity to handle several major insolvencies concurrently is highly doubtful. Indeed, attempting to force surviving carriers to shoulder the burden created by several large insolvencies could actually endanger the health of otherwise-solvent insurers, thereby generating a downward spiral in insurance markets.

285 Texas Department of Insurance, Retained Asset Accounts Survey *2 (2011), online at http://www.tdi.texas.gov/reports/life/documents/raareport.pdf (visited Nov 3, 2014).

286 FSOC, Final Determination Regarding Prudential at *10 (cited in note 148).

287 See Martin F. Grace and Hal S. Scott, An Optional Federal Charter for Insurance: Rationale and Design, in Grace and Klein, eds, The Future of Insurance Regulation in the United States 55, 90-91 (cited in note 19).

288 See id at 89-91; Life and Health Insurance Guaranty Association Model Act $\S 3(\mathrm{C})(2)$ (NAIC July 2009), online at http://www.naic.org/store/free/MDL-520.pdf (visited Nov 3,2014$)$.

289 See Grace and Scott, An Optional Federal Charter for Insurance at 89 (cited in note 287) (noting that the state-guarantee-fund system is "in place to compensate for the losses suffered by third parties and policyholders due to insurance company insolvency"). 
5. Systematic errors in life insurers' reserves.

Perhaps the most common reason that individual insurers fail is that they set aside an insufficient amount of money to pay for future claims. ${ }^{290}$ Such errors in setting policyholder reserves are common in insurance, simply because it is often difficult to predict the frequency and magnitude of future claims. ${ }^{291}$ This is particularly true for insurance policies for which there is a substantial gap of time between the purchase of the policy (when an insurer must set reserves) and the ultimate payout of a claim. Insurers that are experiencing financial difficulty are particularly likely to underreserve in an attempt to mask the degree of their troubles. ${ }^{292}$

Much more troublingly from a systemic-risk perspective, underreserving and underpricing of risk have become repeated and industry-wide phenomena in property-casualty insurance markets. ${ }^{293}$ Indeed, property-casualty markets are generally characterized by oscillation between "hard markets" (in which coverage is relatively scarce and unavailable) and "soft markets" (in which coverage is relatively cheap and available). Even apart from these cyclical patterns in reserving, liability insurers have frequently underestimated reserves due to their failure to anticipate increases in liability exposure resulting from medical malpractice, asbestos, and pollution-remediation expenses. ${ }^{294}$ Similarly, long-term-care insurers substantially underestimated their loss reserves in the 1990s by failing to fully account for large increases in long-term-care expenses as well as the effects

\footnotetext{
290 See Plantin and Rochet, When Insurers Go Bust at 27 (cited in note 278); Cummins and Weiss, Systemic Risk at *36 (cited in note 19) (attributing 29 percent of life insurer insolvencies and 42 percent of property-casualty-insurer insolvencies to inadequate pricing and deficient loss reserves).

291 See Martin F. Grace and J. Tyler Leverty, Property-Liability Insurer Reserve Error: Motive, Manipulation, or Mistake, 79 J Risk \& Ins 351, 353 (2012).

292 See id at 353, 361-63.

293 See generally US Department of Treasury Financial Research Advisory Committee Research Subcommittee, OFR Study on the Insurance Sector Recommendation (Feb 24, 2014), online at http://www.treasury.gov/initiatives/ofr/about/Documents/FRAC \%20Research\%20OFR\%20Study\%20on\%20the\%20Insurance\%20Sector\%20Recommendation .pdf (visited Nov 3, 2014).

294 See Kenneth S. Abraham, The Liability Century: Insurance and Tort Law from the Progressive Era to 9/11 126, 156-62 (2008) (explaining how legal and social changes throughout the second half of the nineteenth century led to new and unexpected forms of insurer exposure in these sectors); L. Lee Colquitt, The Impact of Asbestos and Environmental Reserves Increases on Shareholder Wealth, 10 N Am Actuarial J 17, 17 (2006) (" $[\mathrm{M}]$ ost analysts agree that U.S. insurers are underreserved for asbestos and environmental liability.”).
} 
of an aging population. ${ }^{295}$ These types of systematic errors in reserving have had significant consequences for the availability and structure of future insurance coverage. ${ }^{296}$ But their common reoccurrence is not surprising: competition among carriers for business can lead to overly optimistic estimates of long-term liabilities, particularly when the managers of companies that ultimately control these figures have a strong incentive to focus on short-term results. ${ }^{297}$

In the past, systematic errors in reserving have been limited in the life insurance domain because life insurers have historically faced rigid and conservative reserving rules for life insurance and annuity products. 298 The strictness of these rules is due in part to the extremely long time horizons between the purchase of coverage and the payout of a claim for these products, which creates potentially outsized risks of reserve errors. However, two recent, and related, developments suggest that this longstanding history of conservative reserving in life insurance may not extend into the future.

First, in the last decade or so, life insurers have increasingly used captive insurance companies to escape regulatory rules governing reserve setting, a process that some have referred to as "shadow insurance." 299 Traditionally, captive insurers were simply a way for a traditional noninsurance company, such as Coca-Cola or General Motors, to self-insure its risks rather than purchase conventional insurance. ${ }^{300}$ From this perspective, it

295 See SCOR Global Life, Focus 2012: Long Term Care Insurance *16-19 (SCOR 2012), online at http://www.scor.com/images/stories/pdf/library/focus/LIFE_Focus\%20LTC \%20EN\%2010-2012.pdf (visited Nov 3, 2014).

296 See id at *19 (explaining the response of long-term-care insurers to raise prices and lower coverage); Baker, Medical Malpractice at 60-62 (cited in note 63) (explaining the relationship between the liability insurance crisis and errors in insurers' loss reserves).

297 See US International Trade Commission, Property and Casualty Insurance Services: Competitive Conditions in Foreign Markets 2-13 (2009) (describing the insurancemarket cycle between "soft" and "hard" years).

298 See Steven D. Lash and Rebecca Kao Wang, Demystifying Life Insurance Securitization: XXX and AXXX Securitization Issues and Considerations, 61 Fin Rep 18, 18-19 (2005).

299 Mary Williams Walsh and Louise Story, Seeking Business, States Loosen Insurance Rules, NY Times A1 (May 8, 2011). See also Koijen and Yogo, Shadow Insurance at *4-5 (cited in note 215) (examining the changes in state law that allowed for shadow insurance to operate through captive companies). Shadow insurance may also have the effect of increasing the interconnections between the insurance industry and the banking industry. See Part II.A (discussing banks as guarantors of insurers).

300 See NAIC, Captives and Special Purpose Vehicles at *9 (cited in note 216) (emphasizing the risk to policyholders of this practice, because insurers use it to avoid statutory accounting rules). Although this draft has been approved by the Captives and Special Purpose 
makes little sense for an insurer to set up its own captive. But life insurers realized that they could exploit the rules governing captive insurers to avoid what they deemed to be excessive reserve requirements. ${ }^{301}$ To do this, a life insurer transfers some of its risk to the captive insurer via a reinsurance transaction. ${ }^{302}$ This transaction can reduce reserves because insurers do not need to reserve against risks that are transferred to reinsurers (even if they are affiliated). Meanwhile, captive insurers are subject to a much looser set of solvency rules than ordinary insurers and can generally choose their regulator among any of the states. ${ }^{303}$ According to the New York Superintendent of Financial Services, "[S]hadow insurance ... puts the stability of the broader financial system at greater risk." ${ }^{304}$ Indeed, one recent estimate concludes that "shadow insurance reduces risk-based capital by 53 percentage points and ratings by 3 notches ... imply[ing] a 10-year impairment probability that is four times that implied by the reported ratings." ${ }^{05}$

Vehicle (SPV) Use (E) Subgroup of the Financial Condition (E) Committee of the NAIC, it is still under review (and has not yet been approved) by that full committee.

301 See New York State Department of Financial Services, Shining a Light on Shadow Insurance: A Little-Known Loophole That Puts Insurance Policyholders and Taxpayers at Greater Risk *4-5 (June 2013), online at http://www.dfs.ny.gov/reportpub/ shadow_insurance_report_2013.pdf (visited Nov 3, 2014).

302 See Koijen and Yogo, Shadow Insurance at *5 (cited in note 215).

303 See NAIC, Captive and Special Purpose Vehicles at *14-15 (cited in note 216). A survey of all fifty states conducted by the Captives and Special Purpose Vehicle (SPV) Use (E) Subgroup of the Financial Condition (E) Committee of the NAIC revealed that the differences in solvency standards for captives, as compared to a commercial insurer, include no statutory deposit requirements, no lower minimum-capital and surplus requirements, no RBC requirements, and a lack of mandatory examination. See generally National Association Insurance Commission, Captives \& SPV Use (E) Subgroup: Call for Comment_Survey Results, online at http://www.naic.org/documents/committees_e _cspv_sg_related_docs_survey_results.pdf (visited Nov 3, 2014). See also Robert Stein, Time for an Overhaul of State-Based Regulation, Best's Review 93 (July 2009) ("I have watched with bewilderment the establishment of stringent reserve and capital requirements, only to see regulatory endorsement of the use of offshore and onshore captives to avoid those standards. Some states' recent actions go even further, by apparently eliminating collateral requirements for reinsured reserves.").

304 Benjamin M. Lawsky, Remarks at the 22nd Annual Hyman P. Minsky Conference on the State of the U.S. and World Economies in New York City (Apr 18, 2013), online at http://www.dfs.ny.gov/about/speeches_testimony/sp130418.htm (visited Nov 3, 2014) (emphasizing that shadow insurance "could leave insurance companies less able to deal with losses" because such insurance "does not actually transfer the risk for those insurance policies off the parent company's books, because in many instances, the parent company is ultimately still on the hook for paying claims if the [captive's] weaker reserves are exhausted").

305 Koijen and Yogo, Shadow Insurance at *2 (cited in note 215). 
Second, state insurance regulation is currently embarking on a fundamental change to the rules governing the setting of life insurers' reserves. Rather than requiring a relatively mechanical and conservative approach to this exercise, states are organizing through the NAIC to implement a process of principlesbased reserving (PBR), which would grant insurers substantial discretion to set their own reserves based on internal models of their future exposures. ${ }^{306}$ The role of regulators in this regime would be to oversee insurers' processes for setting reserves and ensure that insurers comply with broad high-level principles. But as the FIO's recent report warned, "State regulators require significant additional technical expertise or resources to properly evaluate the rigor and quality of idiosyncratic reserve models that vary among firms within a heterogeneous insurance industry." ${ }_{07}$ Given the extensively documented inability of federal regulators to fully understand and vet the internal models of financial firms prior to the crisis, ${ }^{308}$ it is unclear whether states will be able to effectively constrain firms' reserving decisions in this new regime.

These developments raise the possibility that a large segment of life insurers could face substantial financial instability due to systematic reserve errors across the industry. Changes in both regulatory rules and regulatory-arbitrage technology have caused or will cause fundamental shifts in the way that most life insurers account for their central liabilities. Yet, as noted above, life insurers potentially face strong incentives to underreserve as a result of the long-term nature of their liabilities and the short-term orientation of management ${ }^{309}$ and shareholders (at least in the case of insurers organized as corporations). ${ }^{310}$ Although persistent underreserving would only gradually weaken insurers, public recognition that many insurers have systematically

306 See Weber, 8 Berkeley Bus L J at 105-15 (cited in note 141) (explaining the development and mechanism of PBR by NAIC).

307 FIO, How to Modernize and Improve at *36 (cited in note 200).

308 See John C. Coffee Jr and Hilary A. Sale, Redesigning the SEC: Does the Treasury Have a Better Idea?, 95 Va L Rev 707, 741-44 (2009) (describing the SEC's inadequate resources in measuring investment banks' compliance with Basel II capital requirements).

309 See Claire Hill and Richard Painter, Berle's Vision beyond Shareholder Interests: Why Investment Bankers Should Have (Some) Personal Liability, 33 Seattle U L Rev 1173, 1184 (2010) (discussing conflicts between the short-term interests of investment bankers and long-term stability).

310 See Henry Hansmann, The Organization of Insurance Companies: Mutual versus Stock, 1 J L, Econ \& Org 125, 131 (1985). 
underreserved for years and are consequently insolvent could well be swift and dramatic.

\section{REGULATORY IMPLICATIONS: EMPOWERING THE FIO TO REGULATE SYSTEMIC RISK IN INSURANCE RESULTING FROM CORRELATIONS AMONG FIRMS}

As described in Part I, the current US insurance regulatory regime delegates virtually all responsibility for regulating the business of insurance (outside of health insurance) to the states. A small handful of insurance-focused financial companiescurrently numbering three-that are individually deemed "systemically important" receive an additional layer of regulatory scrutiny at the federal level. So too do insurance-focused financial companies that own (or are) a depository institution. Part II, however, argued that entire segments of the insurance industry may pose systemic risks to the larger financial system due to correlations in individual insurers' investment activities, underwriting exposures, and risk-management techniques, among others. The logical implication of these two parts is that the federal government currently delegates to the states virtually exclusive responsibility for regulating entire segments of a sector of the financial system that can contribute to systemic risk.

This Part begins by arguing that this is a deep mistake in regulatory architecture. Because systemic risk is, by definition, nationally and internationally significant, it must be regulated-at least in part-at these levels of governance. Therefore, this Part argues that a federal regulator should play a more robust role in overseeing the insurance industry in conjunction with the states. Section B describes one potential option for accomplishing this: empowering the FIO to preempt state law and potentially even conduct its own regulatory activities. To ensure that the FIO exercises this authority judiciously, this Article suggests that any proposals by the FIO to intervene in state insurance regulation to reduce systemic risk would need to be preapproved by FSOC.

\section{A. State Insurance Regulation and Systemic Risk}

State insurance regulation is poorly equipped to address systemic risk in insurance for at least two fundamental reasons. The first and more important involves a central tenet of federalism, 
which has been labeled the "internalization principle": 311 regulatory responsibilities should generally be assigned-at least in part312 - to the unit of government that best internalizes the full costs of the underlying regulated activity. ${ }^{313}$ Thus, the federal government should play an important part in the regulation of pollution that crosses state boundaries, such as air and water pollution. By contrast, individual states should generally regulate potential pollution whose harmful effects would be entirely confined within their boundaries. The rationale for this principle is that government entities will have optimal incentives to take into account the full costs and benefits of their regulatory decisions only if the impacts of those decisions are felt entirely within their jurisdictions. ${ }^{314}$ Delegating to states sole regulatory responsibilities over activities that produce negative externalities nationally or internationally will generally lead to underregulation of those activities. ${ }^{315}$

Because systemic risk in insurance is a negative externality whose effects are felt nationally and internationally, the internalization principle suggests that insurance should be regulated-at least in part-by national and international regulatory bodies. At root, systemic risk in insurance-like all systemic risk-is simply one particular type of negative externality that can arise from the activities of individual insurers: insurers enjoy all the profits attributable to providing coverage in the absence of a financial crisis, but many of the costs of a financial crisis are borne by society at large in the form of diminished macroeconomic

311 Robert D. Cooter and Neil S. Siegel, Collective Action Federalism: A General Theory of Article I, Section 8, 63 Stan L Rev 115, 137 (2010). See also Clayton P. Gillette, Who Should Authorize a Commuter Tax?, 77 U Chi L Rev 223, 233 (2010).

312 Although this caveat is not always included within the internalization principle, it can be explained by the significant literature on cooperative federalism and the like, which shows that, in some cases, cooperation among different levels of government can produce benefits such as decreasing regulatory capture or better accommodating local tastes and preferences. See Amanda Rose, State Enforcement of National Policy: A Contextual Approach (with Evidence from the Securities Realm), 97 Minn L Rev 1343, 1356 (2013).

313 For the origins of this principle, see Wallace E. Oates, Fiscal Federalism 14-16 (Harcourt 1972).

314 See id at 46-47.

315 As Professors Robert Cooter and Neil Siegel note, in a world with zero transaction costs, states could theoretically coordinate with one another to address this type of problem. See Cooter and Siegel, 63 Stan L Rev at 139 (cited in note 311). But because transaction costs with respect to devising such regulation are generally quite high, this type of coordination is practically a limited solution. See id at 139-44. 
activity. ${ }^{316}$ Therefore, state insurance regulators will predictably have insufficient incentives to appropriately regulate activities in insurance markets that can generate systemic risk. Whereas the costs of such regulation are predominantly felt locally-in the form of increased premiums for consumers, decreased profits for insurers, ${ }^{317}$ and decreased premium tax revenues for state governments ${ }^{318}$ - the benefits are enjoyed by a diffuse set of national and international actors to whom local lawmakers are not accountable.

The mismatch between the national and international consequences of systemic risk in insurance and the state regulation of insurance is potentially even worse than this straightforward application of the internalization principle might suggest. As described in Part II.B, one of the important potential drivers of systemic risk in insurance is solvency-based regulation, which is designed to ensure that insurers can pay policyholders when their claims come due. Indeed, it was precisely this type of regulation that caused some insurers to increase their holdings of mortgage-backed securities and then to sell them en masse at the first sign of trouble. ${ }^{319}$ As a result, state-based regulation to protect consumers from less than full payment stemming from insolvencies may ironically exacerbate systemic risk. ${ }^{320}$ Here, as suggested by the internalization principle, state regulators will tend to favor regulation that protects consumers within their state even if such regulation has the side effect of exacerbating systemic risk. But this type of conflict is particularly insidious because it may be hard to identify given the counterintuitive way in which state regulation favors the interests of local constituents over national interests.

316 See Steven L. Schwarcz, Markets, Systemic Risk, and the Subprime Mortgage Crisis, 61 SMU L Rev 209, 212-13 (2008).

317 Most regulation, of course, comes along with costs that are borne by consumers and firms. See Office of Management and Budget, 2013 Report to Congress on the Benefits and Costs of Federal Regulations and Unfunded Mandates on State, Local, and Tribal Entities *10-15 (2013), online at http://www.whitehouse.gov/sites/default/files/omb/ inforeg/2013_cb/2013_cost_benefit_report-updated.pdf (visited Nov 3, 2014) (estimating the costs of regulation).

318 States generate substantial revenue from premium taxes. See Spencer L. Kimball and Ronald N. Boyce, The Adequacy of State Insurance Rate Regulation: The McCarranFerguson Act in Historical Perspective, 56 Mich L Rev 545, 554 (1958).

319 See text accompanying notes 155-91.

320 The notion that financial regulation may exacerbate systemic risk has been explored elsewhere. See Whitehead, 96 Cornell L Rev at 346-58 (cited in note 16); Roberta Romano, For Diversity in the International Regulation of Financial Institutions: Critiquing and Recalibrating the Basel Architecture, 31 Yale J Reg 1, 68-76 (2014). 
All of this suggests that national and international regulatory bodies should be significantly involved in regulating activities that generate systemic risk in insurance. Indeed, in recent decades, the need for such national and international regulation of financial activities that can produce systemic risk has been widely acknowledged. ${ }^{321}$ Thus, the last century has seen a gradual nationalization of regulation in both the banking and securities domains, particularly with respect to issues involving prudential regulation and systemic risk rather than consumer protection. 322 Similarly, it has seen the increasing importance of international norm-setting bodies such as the Basel Committee and the International Organization of Securities Commissions. ${ }^{323}$

Enhancing federal regulation of systemic risk in insurance should promote greater international coordination of systemic risk and insurance. Currently, the International Association of Insurance Supervisors (IAIS) generates soft law on insurance regulation generally, and on the regulation of systemic risk in insurance in particular. ${ }^{324}$ These white papers, principles, and frameworks do not directly bind countries but nonetheless play an important role in the development of insurance regulation globally. ${ }^{325}$ Not surprisingly, however, the state-based framework for insurance regulation in the United States has made

\footnotetext{
321 See, for example, Christopher J. Brummer, How International Financial Law Works (and How It Doesn't), 99 Georgetown L J 257, 269-70 (2011).

322 See id at 273. See also Benn Steil, Regulatory Foundations for Global Capital Markets, in Richard O'Brien, ed, 6 Finance and the International Economy 63, 66 (Oxford 1992) ("Since any systemic effects of inadequate or misguided regulation in one jurisdiction cannot be contained within that single jurisdiction, the imposition of universal standards or modes of operation is likely to be the only effective response."). The more prominent role of states in regulating consumer protection in banking and securities regulation is roughly consistent with the internalization principle, as many consumerprotection issues are felt predominantly within states. Moreover, allowing states to retain some authority over consumer-protection issues, concurrently with the federal government, can serve other goals such as reducing regulatory capture. See Amy Widman and Prentiss Cox, State Attorneys General's Use of Concurrent Public Enforcement Authority in Federal Consumer Protection Laws, 33 Cardozo L Rev 53, 64-65 (2011).

323 See David Zaring, Finding Legal Principle in Global Financial Regulation, 52 Va J Intl L 685, 688-700 (2012).

324 See generally International Association of Insurance Supervisors, Insurance Core Principles, Standards, Guidance and Assessment Methodology (Oct 12, 2013); International Association of Insurance Supervisors, Common Framework for the Supervision of Internationally Active Insurance Groups (Oct 17, 2013). For more on soft law, see generally Chris Brummer, Soft Law and the Global Financial System: Rule Making in the 21st Century (Cambridge 2012) (examining the international system of nonbinding soft law that governs financial institutions).

325 See Brummer, 99 Georgetown L J at 284-90 (cited in note 321).
} 
American participation in this process immensely complicated. ${ }^{326}$ Although Dodd-Frank partially addressed this issue by empowering the FIO to represent American interests internationally, ${ }^{327}$ this approach faces the obvious and important limitation that the FIO itself has no actual regulatory authority over the insurance industry. ${ }^{328}$ As such, the FIO's subscription to international norms in the IAIS has limited influence on individual states, which have often resisted developments at the IAIS relevant to the regulation of systemic risk in insurance. ${ }^{329}$

Aside from the internalization principle, a second fundamental reason that state regulation is poorly equipped to address systemic risk in insurance is that state regulators lack the necessary expertise and perspective. As described above, systemic risk in insurance arises in large part because of the pervasive and ever-changing nature of the interconnections between the insurance industry and the rest of the financial system. ${ }^{330}$ But state regulators have very limited expertise or oversight over any part of the financial system other than insurance. Virtually all securities regulation at the state level is focused on fraudulent sales to consumers or on relatively small offerings. ${ }^{331}$ And while state banking regulation is more robust than state securities regulation, it likewise focuses predominantly on consumer protection and on the regulation of smaller, community

326 See Elizabeth F. Brown, The Development of International Norms for Insurance Regulation, 34 Brooklyn J Intl L 953, 984-88 (2009) (explaining that, because state insurance regulators have a difficult time working together, they are poorly suited to represent national interests in international insurance regulation); Elizabeth F. Brown, Will the Federal Insurance Office Improve Insurance Regulation?, 81 U Cin L Rev 551, 576 (2012) (noting that the fragmented nature of American insurance regulation has frustrated the negotiation of international agreements); Financial Stability Board, Peer Review of the United States *10 (Aug 27, 2013), online at http://www.financialstabilityboard.org/publications/r_130827.pdf (visited Nov 3, 2014) ("While the FIO represents the US on international insurance matters and negotiates covered agreements, only the states have the authority (but are under no legal obligation) to implement laws that are consistent with those agreements and international standards agreed within the IAIS.").

327 See Part I.C.

328 See Brown, 81 U Cin L Rev at 584-85 (cited in note 326) (noting the FIO's limitations in participating in international developments at the IAIS because the FIO is not itself a regulator).

329 See Elizabeth Festa, NAIC Says International Capital Standards Won't Replace State RBC Regime, (LifeHealthPro Dec 15, 2013), online at http://www.lifehealthpro.com/ 2013/12/15/naic-says-international-capital-standards-wont-rep (visited Nov 3, 2014).

330 See Part II.A.

331 See James D. Cox, Robert W. Hillman, and Donald C. Langevoort, Securities Regulation: Cases and Materials 15-16 (Aspen 6th ed 2009). 
banks. ${ }^{332}$ Moreover, state banking regulation operates in conjunction with, and subject to the oversight of, a large number of federal banking regulators, including the FDIC, the Fed, and the Consumer Financial Protection Bureau (CFPB). ${ }^{333}$ Similarly, after Dodd-Frank, virtually all regulation of the shadow-banking system occurs at the federal level. ${ }^{334}$ In sum, the vast majority of regulatory expertise on (noninsurance) financial regulation is located at the federal, rather than the state, level.

To be sure, state insurance regulators can, in theory, attempt to coordinate with federal financial regulators to the extent necessary to regulate issues surrounding systemic risk. But even apart from the internalization principle, these efforts are often unproductive and fraught with posturing and politics. ${ }^{335}$ In large part this is because state insurance regulators are often so preoccupied with maintaining their tenuous grip on authority that they reflexively resist federal involvement in insurance matters, even when it comes from noninsurance federal regulators. ${ }^{336}$ Additionally, such coordination is substantially impeded by the fifty-plus different insurance jurisdictions, each of which may be represented by commissioners with very different views about regulation generally and about the prospect of systemic risk in insurance in particular. ${ }^{337}$

Not only do state insurance regulators have limited knowledge and expertise about noninsurance financial markets, but they often have limited perspective about potential systemwide risk within insurance markets themselves. State insurance regulation in the United States is conducted almost exclusively on a legal entity basis, meaning that insurance regulators focus the bulk of their regulatory scrutiny on individual insurance

332 See Carnell, Macey, and Miller, The Law of Banking at 81-86, 336-37 (cited in note 60) (discussing the interaction between state and federal banking law in the dual banking system and state consumer-protection regulation).

333 See id at 62-64.

334 See Steven L. Schwarcz, Regulating Shadow Banking: Inaugural Address for the Inaugural Symposium of the Review of Banking \& Financial Law, 31 Rev Bank \& Fin L 619, 631-36 (2012) (analyzing Dodd-Frank's various provisions for regulating shadow banking).

335 See Kenneth Meier, The Political Economy of Regulation: The Case of Insurance 84-87 (SUNY 1988).

336 See Daniel Schwarcz, Transparently Opaque: Understanding the Lack of Transparency in Insurance Consumer Protection, 61 UCLA L Rev 394, 457-59 (2014).

337 See FIO, How to Modernize at *31 (cited in note 200) (describing the lack of uniformity in state insurance regulation across a number of different dimensions arising from disagreements among states regarding regulatory priorities). 
companies. ${ }^{338}$ By contrast, insurance regulators do not focus extensive attention on insurance holding companies-the companies that own (often many) insurance companies, as well as other types of financial and nonfinancial companies. ${ }^{339}$ Insurance regulators do not even require aggregate financial reporting at the holding-company level, much less regulate core financial measures at the holding-company level, such as capital levels. ${ }^{340}$ This approach to financial regulation is intimately bound up with the state-based nature of insurance regulation: insurance holding companies operate in numerous jurisdictions through many different subsidiaries, making state coordination with respect to such holding companies much more complicated than state coordination with respect to individual insurers. ${ }^{341}$

States' limited perspective on the operations of insurance holding companies means that insurance regulators are inherently more likely to overlook the potential for systemic risk to emerge within the insurance system. Supervisors of individual entities within a financial conglomerate naturally lack a complete and coherent understanding of the business and risks associated

338 See National Association of Insurance Commissioners, The United States Insurance Financial Solvency Framework 2-3 (2010) (describing the accreditation program and deference by insurance regulators to the solvency regulation of an insurer's domestic state). This approach is combined with rules that attempt to ensure the ring-fencing of individual insurance companies from the risks of their affiliates. Ring-fencing can be understood as legally deconstructing a firm in order to more optimally reallocate and reduce risk. "The deconstruction can occur in various ways: by separating risky assets from the firm, by preventing the firm itself from engaging in risky activities or investing in risky assets, or by protecting the firm from affiliate and bankruptcy [and insolvency] risks." Schwarcz, $87 \mathrm{~S}$ Cal L Rev at 72 (cited in note 200).

339 To be sure, state insurance regulators have recently increased their efforts to understand risks at the holding-company level. First, they have increased their ability to access information about activities within the group and are afforded rights of inspection. See Kris DeFrain, Insurance Group Supervision, CIPR Newsletter (NAIC Apr 2012), online at http://www.naic.org/cipr_newsletter_archive/vol3_ins_group_supervision.htm (visited Nov 3, 2014). Second, they are in the process of adopting a qualitative riskmanagement report, entitled the Own Risk Solvency Assessment, which would be compiled at the holding-company level. See National Association of Insurance Commissioners, Own Risk and Solvency Assessment (May 2014), online at http://www.naic.org/ cipr_topics/topic_own_risk_solvency_assessment.htm (visited Nov 3, 2014).

340 See DeFrain, Insurance Group Supervisors (cited in note 339).

341 To be sure, states do attempt to coordinate their regulation of insurance groups through supervisory colleges and the designation of lead regulators. See FIO, How to Modernize at *42 (cited in note 200). Although valuable, these mechanisms largely act as periodic check-ins among the regulators of the individual insurance companies within the insurance group, rather than as a sustained attempt to regulate the holding company. 
with the conglomerate as a whole. ${ }^{342}$ Risk management, investment strategies, reserving strategies, and the like are all generally determined not by the managers or directors of individual legal entities, but instead by the managers and directors of the holding company. ${ }^{343}$ Because regulation is not focused on the holding company, state insurance regulators risk failing to appreciate potential precursors to systemic risk. All of this is well illustrated by AIG: because insurance regulators focused attention on individual insurers within AIG, they missed the fact that an AIG noninsurer affiliate was using insurers' assets to support risky securities-lending operations. ${ }^{344}$

\section{B. One Option for Enhancing Federal Involvement in State Insurance Regulation: Expanding the FIO's Authority}

The federal role in insurance regulation has been a perennial subject of debate for over half a century. Academics and policymakers have advanced numerous proposals to partially or entirely federalize insurance, and some of these have found their way into proposed legislation. ${ }^{345}$ In most cases, these proposals to enhance federal authority over insurance regulation are principally motivated by the perceived inefficiencies of state regulation, which tends to result in decreased uniformity of regulatory rules and increased compliance costs for insurers. ${ }^{346}$ By contrast, this Article suggests that direct federal involvement in insurance

342 See Andrew Kuritzkes, Til Schuermann, and Scott M. Weiner, Risk Measurement, Risk Management, and Capital Adequacy in Financial Conglomerates, in Robert E. Litan and Richard Herring, eds, Brookings-Wharton Papers on Financial Services: 2003 141, 151 (Brookings 2003) (noting that supervisors of individual subsidiaries within financial conglomerates face challenges in managing risk because they lack a "group-wide perspective").

343 See Elizabeth F. Brown, The New Laws and Regulations for Financial Conglomerates: Will They Better Manage the Risks than the Previous Ones?, 60 Am U L Rev 1339, 1357 (2011). Entity-based regulation has led to other problems including double or multiple gearing, contagion risk, concentration risk, conflicts of interest, and intragroup exposure. See Bank for International Settlements, Principles for the Supervision of Financial Conglomerates Consultative Document 15 (Sept 2012).

344 See Part I.B.

345 See, for example, Schwarcz, 94 Minn L Rev at 1720-24 (cited in note 19).

346 See, for example, Henry N. Butler and Larry E. Ribstein, The Single-License Solution, 31 Reg 36, 36-38 (2008-2009); Grace and Scott, An Optional Federal Charter at 59-75 (cited in note 287); Martin F. Grace and Robert W. Klein, Insurance Regulation: The Need for Policy Reform, in Grace and Klein, eds, The Future of Insurance Regulation in the United States 117, 126-30, 134-39 (cited in note 19). See also generally Peter J. Wallison, ed, Optional Federal Chartering and Regulation of Insurance Companies (American Enterprise Institute 2000). 
regulation is necessary to address the potential that systemic risk in insurance might arise within entire sectors of the insurance industry.

One potentially sensible way to respond to this risk would be to enhance the capacity of the FIO to shape insurance regulation when it has credibly determined that doing so is necessary to help monitor, manage, or prevent systemic risk in insurance. The FIO is relatively well situated to take on this role for the very reasons that states are not. First, the FIO is politically accountable to a federal constituency: the president appoints the director of the FIO, and the FIO itself is housed within the Department of the Treasury. ${ }^{347}$ For these reasons, the FIO would generally internalize the potential costs and benefits of regulations that attempt to target the prospect of systemic risk in insurance. ${ }^{348}$ Additionally, as noted earlier, Dodd-Frank envisions the FIO as the primary representative of the country's interests in international discussions of insurance regulation in fora such as the IAIS. ${ }^{349}$ Elevating the power of the FIO to address the prospect of systemic risk in insurance-something that the international community has expressly endorsed in its own "peer review" of US insurance regulation ${ }^{350}$ - would help support the development of international norms and coordination on regulating systemic risk and insurance, consistent with the internationalization principle and the international ramifications of systemic risk.

Second, the FIO's current structure and statutory responsibilities give it a good deal of expertise in systemic risk. Under Dodd-Frank, the FIO's director is a nonvoting member of FSOC, meaning that he and his staff are actively involved in thinking about systemic risk in insurance. ${ }^{351}$ Indeed, the first statutory goal of the FIO is to monitor the insurance industry and its regulation for potential systemic risk. ${ }^{352}$ The FIO's placement within the Department of the Treasury means that it can draw on the expertise and perspective of various federal agencies and

\footnotetext{
347 See Dodd-Frank $\S 313(a), 124$ Stat at 1580, codified at 31 USC $\S 313(a)$.

348 See Part III.A.

349 See Part III.A.

350 See Financial Stability Board, Peer Review at *11-12 (cited in note 326) ("The FIO should enhance its monitoring of the sector through increased use of non-public information, and be further strengthened to be able to take action to address issues and gaps identified.”).

351 Dodd-Frank $\S 502(a)(3), 124$ Stat at 1581, codified at 31 USC $\S 313(\mathrm{c})(3)$.

352 Dodd-Frank § 502(a)(3), 124 Stat at 1580, codified at 31 USC § 313(c)(1)(A).
} 
departments that regulate financial affairs. ${ }^{353}$ So too can it draw on the views of a variety of experts, through a Federal Advisory Council on Insurance that advises the FIO. ${ }^{354}$

There are various potential approaches to allowing the FIO to take on an enhanced role in shaping state insurance regulation to monitor and account for systemic risk. ${ }^{355}$ Perhaps the most sensible is to empower the FIO to develop federal standards that would then preempt state laws if they were not adequately implemented by the states. ${ }^{356}$ This type of power would be most useful in allowing the FIO to address systemic risks that arise due to inadequacies in the specific laws and regulations of states. For instance, the FIO has suggested that shadow insurance poses a potential for systemic risk. ${ }^{357}$ One of the big problems in this domain is that carriers can choose to establish their captives in any state. ${ }^{358}$ This has arguably resulted in a race to the bottom as a few states have developed particularly lax rules for such captives regarding issues such as what types of assets can be held against liabilities. ${ }^{359}$ Empowering the FIO to set minimum standards for captives of insurance companies could help address this risk.

As the FIO's modernization report recognizes, this approach would prove more challenging to the extent that it involves not simply the preemption of state laws, but the establishment of additional requirements for certain sectors of the insurance industry. ${ }^{360}$ The effectiveness of any such affirmative federal requirements would depend on the quality and uniformity of their enforcement. ${ }^{361}$ The FIO thus suggests that this type of approach "must specify standards, processes, and a deadline in order to

\footnotetext{
353 See Jody Freeman and Jim Rossi, Agency Coordination in Shared Regulatory Space, 125 Harv L Rev 1131, 1184-86 (2012) (arguing that interagency coordination helps agencies improve their decisionmaking process).

354 See US Department of the Treasury, Application for Membership on the Federal Advisory Committee on Insurance, 79 Fed Reg 1672, 1672-73 (Jan 9, 2014).

355 See FIO, How to Modernize at *8-10 (cited in note 200) (discussing various potential approaches to enhancing federal involvement in insurance regulation).

356 This proposal is described as a "state passport" system in the FIO's modernization report and was originally suggested by the Financial Services Roundtable. See id at *9.

357 See id at *32-34.

358 See Part II.B.

359 See FIO, How to Modernize at *1 (cited in note 200).

360 See id at *8.

361 See id at *9.
} 
minimize or eliminate the prospect of variance among the states." 362

Another potential solution to this dilemma would be to empower the FIO to take over enforcement authority in cases in which state enforcement is deemed to be lacking. In many ways, this approach would resemble that embraced by the Affordable Care Act, under which states are permitted to establish their own insurance exchanges, but the federal government retains the authority to do this if states refuse. ${ }^{363}$ This type of solution would likely be effective only if most states generally accepted the invitation to enforce FIO-promulgated rules. The FIO's budget and resources are not designed to support an active enforcement regime. ${ }^{364}$ However, state refusal to enforce federally developed standards would presumably be much less likely in this setting than in the health insurance setting. ${ }^{365}$ Health care reform has, of course, been immensely controversial, and states' refusal to implement a federal regime can be almost entirely attributed to that fact. ${ }^{366}$ It is hard to imagine that a narrow increase in the FIO's regulatory authority would occasion anything like this type of controversy. Moreover, a key factor in states' resistance to developing insurance exchanges was the fact that these exchanges would require the development of an entirely new state entity. ${ }^{367}$ By contrast, the proposal here would simply permit enforcement by an existing agency.

A key benefit of empowering the FIO to preempt state law and promulgate its own regulations would be that it would force states to work actively and cooperatively with the FIO. To this point, states have either resisted or ignored many of the FIO's suggestions. For instance, states have refused to allow the FIO to attend meetings of supervisory colleges-wherein regulators discuss the risks associated with entire holding companies-by arguing that the FIO's involvement would not be appropriate. ${ }^{368}$

\footnotetext{
362 Id.

363 See Affordable Care Act $\S 1321(c)$, Pub L No 111-148, 124 Stat 119, 186, codified at 42 USC $\S 18041$.

364 See Financial Stability Board, Peer Review at *31, 36 (cited in note 326) (noting the FIO's limited resources).

365 For discussion of states' refusal to establish their own insurance exchanges, see generally David K. Jones and Scott L. Greer, State Politics and the Creation of Health Insurance Exchanges, 103 Am J Pub Health e8 (2013).

366 See id at e9.

367 See id at e8.

368 See Leonardi Testimony at *2 (cited in note 121) (resisting various reform recommendations suggested by the FIO, particularly the participation of the FIO in supervisory
} 
Presumably, states would take a more accommodating perspective on including the FIO within supervisory colleges if the FIO was given clear authority to preempt state law.

To be sure, empowering the FIO as we suggest could result in it using this authority to unduly aggrandize its influence. The risk of regulatory aggrandizement is a common concern in regulatory design. ${ }^{369}$ This risk might be heightened here, as the FIO's influence has historically been limited and might remain so in the absence of it using the authority contemplated herein. Additionally, the FIO's limited independence and budgetary authority also raise potential difficulties that might have to be addressed in any legislative effort to enhance the FIO's role in insurance regulation.

One potentially effective way to guard against this type of risk would be to require the FIO to secure the approval of some percentage of voting members of FSOC before promulgating new rules that would preempt state law. In that context, FSOC might be asked to determine whether the proposed rules are truly necessary to address the legitimate prospect of systemic risk in insurance. ${ }^{370}$ As part of that determination, FSOC might consider the extent to which state regulators have been given a fair and reasonable opportunity to address the deficiencies in state regulation that the FIO would target. Because state insurance regulators also have their own nonvoting member on FSOC, 371 there would be limited risk that the FIO would be able to present a one-sided story about the need for targeted federal intervention to address systemic risk.

Ultimately, various options other than expanding the FIO's authority are available to enhance federal involvement in state insurance regulation. To take the most obvious example, the federal government might simply create an optional or mandatory federal charter for insurers. Such proposals implicate numerous issues other than systemic risk, including regulatory

colleges, as the "presence of a non-regulator, even as well intentioned as Treasury, would threaten the objective independence of not just state regulators, but regulators at the federal and international levels who participate in the colleges, as well").

369 See, for example, Stephen J. Choi and Andrew T. Guzman, Portable Reciprocity: Rethinking the International Reach of Securities Regulation, 71 S Cal L Rev 903, 923 (1998) (observing that "regulators benefit from increased size and importance of their own agencies").

370 This approach would resemble FSOC's current role in reviewing regulation by the CFPB that could undermine systemic stability. See Dodd-Frank § 1023(a), 124 Stat at 1985, codified at 12 USC $\S 5513$ (a).

371 Dodd-Frank § 111(b)(2), 124 Stat at 1393, codified at 12 USC § 5321(b)(2). 
uniformity, international coordination, and the substantive desirability of state insurance regulation. But this Article suggests that at least one generally underappreciated virtue of most such proposals is that they would enhance federal involvement in the regulation of insurance markets, and thus the capacity of the federal government to identify, monitor, and respond to the aggregation of systemic risk in that sector.

\section{CONCLUSION}

Although insurance companies and their affiliates played a central role in the 2008 financial crisis, this country's regulatory response has focused on preventing a reoccurrence of the 2008 events instead of trying to more broadly understand why and how insurers can be systemically risky. This Article argues that insurance-focused financial firms can be systemically risky not only due to their size-which is currently the primary focus of federal regulation in insurance, spurred by AIG's near failurebut also due to commonalities and correlations in insurance products, investment strategies, risk exposures, risk management, and interconnections to the larger financial system. Moreover, we argue, these commonalities, correlations, and interconnections are constantly changing, both in response to market changes in the insurance industry and the changing role of insurance within the larger financial industry.

Systemic risk regulation therefore presents a dynamic challenge, requiring an insurance regulatory structure designed to proactively identify, assess, and manage new potential sources of systemic risk from the perspectives of the overall insurance industry and its place within the financial system. The traditional system in the United States of state-based insurance regulation cannot adequately accomplish that. The fragmented nature of state regulation often prevents regulators from seeing overall risks - such as the risks posed by an insurance holding company that operates through multiple out-of-state subsidiaries. States also have inadequate incentives to police against those risks. Their traditional goals include consumer protection and premium tax collection; they have not focused on protecting against systemically caused harm. Furthermore, state regulators are unlikely to understand the changing role of insurance within the larger financial industry; indeed, states have little regulatory authority and expertise over that larger industry because banking and securities regulation are almost entirely federally regulated. 
We therefore argue that the traditional state insurance regulatory regime should be supplemented by national regulation of systemic risk in insurance. This could occur, for example, by expanding the authority of the US Treasury Department's FIO, originally created by the Dodd-Frank Act to have a limited monitoring role. That office itself recently suggested the potential need for more robust federal intervention in state insurance regulation. Any expanded authority of the FIO, we contend, should include the power to supplement-and in appropriate cases, even to preempt-state insurance laws if and when necessary to control systemic risk. The FIO should be well positioned to regulate systemic risk given its accountability to a national constituency as well as its mandate to develop a global perspective on the insurance industry. 